\title{
IDEIAS EM OUTRO LUGAR? \\ Constituição liberal e codificação do direito privado na virada do século XIX para o século XX no Brasil
}

\section{Marcelo Neves}

Universidade de Brasília (UnB), Brasília - DF, Brasil. E-mail: marceloneves@unb.br

DOI: http//dx.doi.org/10.17666/308805-27/2015

\section{Introdução}

O debate referente à introdução de concepções jurídico-políticas liberais no Brasil concentra-se, historicamente, na divergência entre duas compreensões básicas: uma aponta para um afastamento da autenticidade cultural mediante a importação de elementos estrangeiros, negadores da identidade, singularidade ou peculiaridade do Brasil ou da "nação" brasileira; a outra sugere uma falta, um defeito na incapacidade de implementação de valores liberais, superiores em termos civilizatórios, a serem seguidos como modelos. Além do espaço da política e do direito, a primeira orientação encontra uma expressão literária na famosa formulação de Machado de Assis: "O país real, esse é bom, revela os melhores instintos; mas o país oficial, esse é caricato e burlesco" (Machado de Assis, [1861] 1955, p. 104). ${ }^{1}$

Artigo recebido em 03/10/2013

Aprovado em 19/03/2015
E ele acrescentava: "Há certas fortunas políticas de nossa terra que não têm explicação" (idem, p. 105). ${ }^{2}$ A orientação oposta manifesta-se na afirmação de Tobias Barreto, ao comparar a experiência do poder moderador, instituído pela Constituição de 1824, à luz do parlamentarismo inglês: "As instituições que não são filhas dos costumes, mas um produto abstrato da razão, não aguentam por muito tempo a prova da experiência, e vão logo quebrar-se contra os fatos. Indubitavelmente o nosso governo se acha em tal estado" (Barreto, [1871] 2000, p. 383). ${ }^{3}$ Aditava ainda: "Mas importa não esquecer que na produção dos nossos males figura em grande parte a cumplicidade do povo" (idem, p. 383). ${ }^{4}$ Essas duas formas de considerar a relação entre "país real" e "país oficial" ou, do ponto de vista especificamente político-jurídico, de tratar a presença de ideias e instituiçôes liberais de origem europeia no Brasil são expressōes diversas de uma autocompreensão que foi chamada, sugestivamente, de "ideias fora do lugar" (Schwarz, [1977] 2000). ${ }^{5}$ 
A esse debate subjaz a concepção de que há uma sociedade brasileira com identidade própria, que a distingue das sociedades europeias. Daí decorre a busca incessante pela peculiaridade, singularidade ou autenticidade do Brasil. Nesse contexto, a noção de sociedade fica vinculada ao conceito político-cultural de Estado nacional, envolvendo a própria territorialidade. A "nação" como conceito cultural desempenha, nos termos da tradição romântica do século XIX, um papel decisivo. A nação brasileira é apresentada como expressão cultural de uma sociedade determinada, enquanto o Estado é compreendido como manifestação política da nação. Disso resultariam uma semântica e uma estrutura próprias da sociedade brasileira, que possibilitariam a sua compreensão e explicação. É nesse sentido que se construiu o rótulo "intérpretes do Brasil". ${ }^{6}$

Parto, porém, do pressuposto teórico segundo o qual a sociedade moderna emerge como sociedade mundial (Neves, 2009, pp. 26ss.; 2008, pp. 215 ss.). ${ }^{7}$ Ao contrário das sociedades pré-modernas, formações territorialmente delimitadas, desenvolve-se, a partir do século XVI, a mundialização da sociedade, que se intensifica no século XIX e se consolida nos fins do século XX, com a afirmação, inclusive no plano semântico da autodescrição, da mundialidade da sociedade, mediante o discurso da globalização (Neves, 2009, pp. 27-28; Luhmann, 1997, p. 148; Brunkhorst, 1999, p. 374). Embora originariamente o sistema econômico tenha sido propulsor do surgimento da sociedade mundial, não se trata apenas de uma característica do capitalismo ou do sistema econômico. ${ }^{8}$ Característico da sociedade mundial é o fato de que o horizonte das comunicações e das expectativas passa a ser primariamente mundial, não se limitando a um determinado território.

Daí por que a relação entre semântica e estrutura deve ser considerada, em primeiro plano, do ponto de vista da sociedade mundial. Considerada a semântica como "um sentido disponível, generalizado de forma mais elevada, relativamente independente da situação" (Luhmann, 1980, p. 19), cabe indagar como se afirmariam construções semânticas como autodescrições da sociedade mundial, considerando a presença, nesta, de situações tão diversas no plano das estruturas (expectativas socialmente estabilizadas). Em primeiro lugar, cumpre observar que o "ideário não pode variar arbitrariamente em relação à sociedade que o utiliza. O problema teórico desloca-se, com isso, para a questão de estabelecer mediante o que e de que maneira a estrutura da sociedade limita a arbitrariedade" (idem, p. 17). Em segundo lugar, cumpre sublinhar que, tomadas a complexidade e a diferenciação como fundamentais para a conexão entre estrutura e semântica, as "relações particulares e gerais entre estrutura da sociedade e semântica caminham, portanto, lado a lado e se influenciam reciprocamente" (idem, p. 34). Isso não exclui que artefatos semânticos se tornem obsoletos perante as novas estruturas emergentes. ${ }^{10}$ Entretanto, é inegável não apenas que inovações semânticas resultem de transformações estruturais, mas também que uma nova semântica estimule mudanças na estrutura social. A questão se complica quando se considera essa relação no plano da sociedade mundial. Um artefato semântico da sociedade mundial pode variar em face de sua adequação à reprodução das estruturas em contextos sociais diversos. Além do mais, cabe distinguir entre semântica referente às estruturas cognitivas e semântica concernente às estruturas normativas.

Como as estruturas cognitivas da economia, da técnica e da ciência não se diferenciam segmentariamente no âmbito da sociedade mundial, a semântica dominante nessas esferas tem um potencial de apresentar-se enfaticamente no plano mundial, sendo pouco importantes as diferenças regionais de estruturas. Assim, a semântica alternativa local é neutralizada em ampla medida, subordinada que fica à semântica da sociedade mundial: autodescrição da produção, circulação, mercado, concorrência, eficiência etc. No que diz respeito, porém, às estruturas normativas do direito e da política, a segmentação territorial em Estados põe não só a questão da semântica mundial em face de estruturas variadas, mas também o problema de artefatos semânticos referentes às estruturas normativas que se reproduzem no âmbito do respectivo Estado.

A semântica mundial do liberalismo tem uma vertente relacionada com as estruturas cognitivas, servindo à autodescrição da economia capitalista, com forte tendência a neutralizar alternativas se- 
mânticas. Já o liberalismo como semântica jurídico-política tem uma forte dimensão normativa. Isso significa que, nos séculos XIX e XX, a semântica liberal da sociedade mundial não só passou por testes de adequação em face de estruturas normativas dos respectivos Estados em que ela foi adotada, mas também foi entrecortada por uma semântica local que lhe subverteu, em grande parte, o sentido e a função originários. Há deslocamentos que transmudam ideias. É com base nesses pressupostos que farei a análise da semântica liberal referente ao constitucionalismo e à codificação do direito privado na experiência brasileira da virada do século XIX para o século XX. Em vez de "ideias fora de lugar", não caberia indagar sobre o sentido e a função do desenvolvimento de ideias em outro lugar, ou melhor, em diversos lugares da sociedade mundial? A sociedade no Brasil da virada do século XIX para o século XX, delimitada pelo Estado como organização político-jurídica territorial, não seria um desses lugares em que as ideias liberais não só se irradiaram como pertencentes à semântica dominante ou hegemônica da sociedade mundial em relação às estruturas normativas, mas também foram confrontadas com semânticas locais antiliberais?

Observe-se que não se trata neste artigo de uma revisão bibliográfica de uma vasta discussão em torno dos intérpretes do Brasil, tampouco de uma retomada do debate entre historiadores sobre "ideias fora do lugar" no Brasil. Antes, o argumento concentra-se na questão jurídica do significado das ideias liberais na codificação do direito privado e da constitucionalização na virada do século XIX para o século XX, a partir de uma releitura da concepção sistêmico-teórica de estrutura e semântica da sociedade mundial. ${ }^{11}$

$\mathrm{Na}$ exposição que se segue, analisarei, inicialmente, os fatores que impediram a codificação unificada do direito privado ou a codificação do direito civil no século XIX, apesar de sua previsão expressa na Constituição imperial de 1824 . No segundo momento, considerarei os limites da concretização normativa da Constituição republicana de 1891 perante as estruturas e as práticas político-jurídicas dominantes no Brasil da Primeira República, apontando para o seu significado simbólico. Em seguida, farei uma breve avaliação do sentido e da função da codificação civil consumada em 1916 no contexto brasileiro das duas primeiras décadas do século XX. Por fim, nas observaçôes finais, considerarei que a adoção de ideias sociais, socialistas ou fascistas nas décadas de 1920 e 1930 não altera substancialmente o quadro de deslocamento semântico de ideias na experiência jurídico-política brasileira, situação que perdura, em certa medida, até hoje; também acentuarei a assimetria na circulação de ideias liberais na sociedade mundial, assim como o paradoxo da localidade e da mundialidade de seu sentido e suas funções.

\section{A ausência de codificação do direito civil no Brasil do Século XIX}

Declarada a Independência em 1822, a Lei de 20 de outubro de 1823, expedida pela Assembleia Constituinte, manteve em vigor as Ordenaçôes Filipinas, leis, alvarás, decretos e resoluções promulgadas pelos reis de Portugal até 25 de abril de 1821, enquanto não entrasse em vigor um novo Código (Pontes de Miranda, [1928] 1981, p. 66; Gomes, 1958, pp. 12-3; Alves, 2003, p. 3). Dissolvida a Assembleia Constituinte em novembro de 1823, o imperador outorgou a Constituição imperial de $1824,{ }^{12}$ cujo art. 179 , inciso XVIII, estabeleceu que se organizasse quanto antes um Código Civil. ${ }^{13}$ Apesar de várias tentativas de concretização dessa previsão constitucional, ela não se realizou durante o período imperial.

As Ordenações Filipinas, publicadas em 1603, no período em que Portugal estava sob o domínio espanhol, e confirmadas pela Lei de 29 de janeiro de 1643, vigoraram durante todo o período monárquico e perduraram, nos termos do art. 83 da Constituição de $1891,{ }^{14}$ nos primeiros 25 anos do regime republicano, até 31 de dezembro 1916, tendo completado 314 anos de vigência no Brasil (Gomes, 1958, pp. 8 e 13; Pontes de Miranda, [1928] 1981 , pp. 41 ss.). Seu anacronismo residia em atribuir "autoridade extrínseca às opiniões de Acúrsio e Bártolo, numa época em que já estavam desacreditadas" (Gomes, 1958, p. 9). Em sua aplicação, os argumentos de autoridade eram dominantes, contentando-se os juízes "com fazer acompanhar as 
suas decisões de um longo préstito de autores, não só jurisconsultos, mas até moralistas e casuístas, o que na linguagem do tempo constituía opinião comum" (Pontes de Miranda, [1928] 1981, pp. 4344). ${ }^{15}$ A Lei de 18 de agosto de 1769, editada no regime do Marquês de Pombal, chamada de "Lei da Boa Razão", procurou enfrentar esse problema ao oferecer critérios para a interpretação e a integração das lacunas da lei e ao exigir que as opinióes dos doutores fossem conferidas à luz da "boa razão", inclusive estabelecendo, em seu $₫ 13$, que Acúrsio e Bártolo, na autoridade que lhes foi atribuída pelas Ordenações Filipinas ( $\$ 1^{\circ}$ do título 64 do livro 3o), fossem destituídos (Pontes de Miranda, [1928] 1981, pp. 44ss; Gomes, 1958, pp. 9ss.).

Com as alteraçōes introduzidas pela "Lei da Boa Razão”, persistiram as Ordenações Filipinas até o primeiro quartel da República, a mercê do que determinara a própria Constituição imperial de 1824: a organização de um código civil "quanto antes". As tentativas nesse sentido não tiveram sucesso.

Em 15 de fevereiro de 1855, o jurista Teixeira de Freitas foi encarregado do trabalho de consolidação da legislação vigente no Brasil, inclusive a de Portugal, anterior à Independência (Meira, 1983, p. 94; Gomes, 1958, p. 18). Buscava-se consolidar, classificar, ordenar, para, depois, codificar ou, na linguagem de Pontes de Miranda, "primeiro conhecer-se para depois expressar-se" ([1928] 1981, p. 79). ${ }^{16}$ Em 1857, Teixeira de Freitas concluiu a obra Consolidação das leis civis ([1857] 2003), ${ }^{17}$ organizando amplamente "os mais esparsos e infirmes elementos legislativos então vigentes e oriundos de 1603 a 1857" (Pontes de Miranda, [1928] 1981, p. 80). Entretanto, Teixeira de Freitas ignorou em sua consolidação a escravatura, instituto em que se assentava a estrutura econômica e jurídica do Império. Nesse sentido, ele justificava sua posição na introdução à sua obra:

Cumpre advertir, que não há um só lugar de novo texto, onde se trate de escravos. Temos, é verdade, a escravidão entre nós; mas, se esse mal é uma exceção, que lamentamos, condenado a extinguir-se em época mais ou menos remota, façamos também uma exceção, um capítulo avulso, na forma das nossas Leis Civis; não as maculemos com disposições vergo- nhosas, que não podem servir à posteridade; fique o estado de liberdade sem o seu correlativo odioso. As Leis concernentes à escravidão (que não são muitas) serão pois classificadas à parte e formarão o nosso Código Negro (Freitas, [1857] 2003, vol. 1, p. xxxvii). ${ }^{18}$

Essa formulação já é um sintoma do complicado convívio com ideias jurídicas liberais no contexto do Brasil imperial. A noção moderna de direito civil como expressão normativa da autonomia privada expóe-se a uma situação vexatória. O jurista liberal, diante das relações escravocratas, procura deslocar o tratamento do problema "vergonhoso" para outro diploma normativo, o "Código Negro", que se reduziria a uma exceção passageira ("odiosa"), pois não poderia "servir à posteridade". Buscando afirmar a coerência liberal da Consolidação com o recurso à exceção antiliberal, Teixeira de Freitas pretendia não só manter a semântica do liberalismo jurídico - referente a estruturas normativas - em consonância com estruturas econômicas da sociedade mundial de então, mas também ajustá-la à semântica local concernente às estruturas de expectativas normativas que embasavam a escravidão. O ideário do liberalismo jurídico era entrecortado e delimitado, dessa maneira, por um escravismo condizente com as estruturas de expectativas cognitivas (econômicas) da sociedade mundial e fortificado pela semântica de identidade referente às estruturas normativas do Estado monárquico brasileiro. As ideias deslocavam, "migravam", sem compromisso com o seu eventual topos de origem.

A dificuldade de Teixeira de Freitas era tanto maior na medida em que o texto constitucional de 1824, como estrutura normativa formal básica do Império brasileiro, previa implicitamente, a escravidão. Embora essa nuance tenha sido desconsiderada, fazendo-se crer que, ao contrário do projeto da Assembleia Constituinte de 1823, a Constituição de 1824 não previu a escravidão, esta reconheceu indiretamente o regime escravocrata ao distinguir, em seu art. $6^{\circ}$, inciso I, entre cidadãos ingênuos e libertos. Tal distinção só tem sentido em ordens escravocratas, uma vez que a condição de liberto supõe a situação anterior de escravo, ao contrário dos que nasceram livres (ingênuos). ${ }^{19}$ 
Foi nesse contexto que também Teixeira de Freitas foi contratado pelo governo imperial, em 10 de janeiro de 1859, para elaborar o esboço de um código civil (Nabuco, [1897-1899] 1997, p. 1053; Meira, 1983, p. 185; Pontes de Miranda, [1928] 1981 , p. 80). Agora, não se tratava mais da construção de um artefato de autodescrição sistemática de estruturas normativas dominantes, mas sim de envolver-se na reforma e transformação dessas estruturas, ao menos na dimensão formal de textualização (Nabuco, [1897-1899] 1997, p. 1054). O esboço não foi concluído, não tendo sido completado o terceiro livro da parte especial, referente às disposiçōes comuns aos direito pessoais e reais, a saber, herança, concurso de credores e prescrição. ${ }^{20}$ Por fim, em 1872, o contrato de redação do projeto foi rescindido, pois o governo não aceitou a ideia de elaborar um código geral do direito privado, defendida por Freitas. ${ }^{21}$ Este, em proposta enviada ao governo em 1867, sustentara o seguinte:

O governo quer um Projeto de Código Civil para reger como subsídio ao complemento do Código do Comércio; intenta conservar o Código Comercial existente com a revisão, que lhe destina, e hoje as minhas ideias são outras, resistem invencivelmente a essa calamitosa duplicação de Leis Civis, não distinguem, no todo das leis desta classe, algum ramo, que exija um código do comércio. O governo só pretende de mim a redação de um Projeto de Código Civil, e eu não posso dar esse código, ainda mesmo compreendendo o que se chama Direito Comercial, sem começar por um outro código, que domine a legislação inteira (apud Nabuco, [1987-1989] 1997, p. 1057).22

Observe-se que o Código Comercial brasileiro fora promulgado em 1850. Teixeira de Freitas alegava que os seus redatores teriam mercantilizado todas as relações civis (Freitas, 1878, pp. xi-xii; Mercadante, 1980 , p. 184). A relativa facilidade com que se aprovou o Código Comercial contrastava com os obstáculos que se punham no governo e no parlamento em relação ao Esboço (Mercadante, 1980 , pp. 189 ss.). Nesse particular, ressalta-se, novamente, a questão do escravismo. O Código
Comercial não entrava em dissonância com o regime escravocrata, pois, ao contrário, os senhores rurais estavam envolvidos nas relações de produção e circulação da economia mundial e necessitavam de uma regulação mercantil moderna:

O senhor rural [...] não podia dispensar, no âmbito do direito privado, um corpo de leis liberais que viessem a regular as suas relações de vendedor com o mercado, onde ele colocava, como comerciante, o que sobejava da produção de sua fazenda. Nesse campo, seus interesses coincidiam com os do comércio exportador das cidades-portos. Vinculavam-se a exportadores e comissários ou ainda a pequenos comerciantes num complexo de relaçóes sociais, mercantis e jurídicas (Mercadante, 1980, p. 184).

Teixeira de Freitas reagia à dualidade do direito privado por ser contrário à "duplicidade em nossas relações de produção" (Mercadante, 1980, p. 190). A sua fuga "engenhosa" da questão servil, ao sugerir um "Código Negro" fora da Consolidação das Leis Civis, não poderia mais ser um caminho, pois, no novo contexto, tratava-se da elaboração do projeto de "um Código em consonância com o individualismo jurídico" (idem, p. 188). A Consolidação serviu à manutenção das estruturas normativas existentes, enquanto o Esboço serviria a uma codificação fundada no individualismo liberal. Aquela poderia conviver com o regime escravocrata, este expunha-se a um paradoxo: a codificação individualista do direito privado - liberal e universalista na autodescrição semântica - exigiria a superação do regime de escravidão ou, no mínimo, caso aprovada, poria em xeque esse regime. Nesse sentido, a Consolidação, ajustada às estruturas sociais escravocratas, teria sido o fator decisivo para que o Esboço não fosse adotado, mostrando-se evidente "a incompatibilidade entre o individualismo jurídico e as condições objetivas da realidade econômica brasileira” (idem, p. 191).

A esse respeito, cabe observar que, embora não tenha sido adotado no Brasil, o Esboço teve forte influência na legislação de outros países, como Argentina, Uruguai, Paraguai e Chile (Pontes de Miranda, [1928] 1981, p. 63; Mercadante, 1980, p. 194). ${ }^{23}$ Nesses países, porém, a escravidão já havia 
sido abolida, o que tornou viável a adoção da codificação individualista do direito privado, adaptada evidentemente às variáveis locais.

Essas consideraçôes sobre o malogro da codificação civil ou unificada do direito privado no período imperial, ${ }^{24}$ que até o seu ocaso manteve a escravidão, contêm indícios que podem evidenciar os próprios limites do deslocamento de ideias em contextos jurídico-políticos diversos. Sem dúvida, o liberalismo jurídico implica ideias que são construçôes pertencentes à semântica da sociedade mundial no século XIX. Nesse plano, embora entrecortadas por semânticas normativas de identidade do Estado-nação, elas circulavam, ao seu modo, no discurso político e jurídico do Império brasileiro. Porém, na medida em que pretenderam ganhar força e tomar forma institucional como artefato estrutural de caráter normativo no plano local, elas se expunham a obstáculos quase intransponíveis: o regime escravocrata, pertencente à estrutura econômica da sociedade mundial do século XIX, legitimado por semântica e estrutura normativa local da autenticidade, tornava improvável a institucionalização das ideias liberais individualistas mediante a codificação do direito civil. Daí por que, nessas circunstâncias, em termos estruturais, "só se efetivaria a revogação das Ordenaçōes com o término das relaçôes escravista" (Mercadante, 1980, p. 194).

Essa afirmação não deve ser interpretada, porém, em termos de um determinismo excludente entre codificação civil e escravidão. O Código Civil de Louisiana, por exemplo, previa a escravidão. A assertiva deve ser compreendida nos limites do contexto brasileiro e da pretensão de Teixeira de Freitas de ser fiel às ideias jurídicas liberais (Fonseca, 2011, pp. 24-25). ${ }^{25}$ Além disso, caberia não considerar apenas a escravidão como obstáculo à codificação civil liberal no Brasil do século XX, mas também as disputas em torno do sentido da cidadania em geral (Grinberg, 2002, espec. pp. 319-321; 2008, pp. 47ss.). Pode-se acrescentar que a Consolidação, assumindo praticamente o papel de uma codificação civil, apresentava-se mais adequada e "funcional" à estrutura de exclusão jurídica e social do Império do que um código civil ou privado de cunho consistentemente liberal, que poderia constituir um perigo à manutenção do arcabouço sociopolítico e jurídico-econômico da Monarquia.
Entretanto, no plano da semântica, as ideias individualistas liberais do direito privado circulavam com funçōes e sentidos diversos dos lugares de sua suposta origem, não apenas como artefatos político-simbólicos de autodescrição ideológica da realidade jurídica e social do país, mas também como elementos reflexivos e críticos da forma de integração do Estado brasileiro na sociedade mundial. O paradoxo entre mundial e local, manifestando-se especificamente, condicionava e estimulava a migração de ideias liberais concernentes à codificação do direito privado no Brasil do século XIX.

\section{Da Constituição liberal de 1891}

Abolida a escravidão em 1888, uma das bases de sustentação econômico-social do regime monárquico, e no contexto dos conflitos do governo com setores militares e religiosos, é proclamada a República, em 1889, singularmente mediante um golpe militar, um tanto inesperado e incompreensível para a população. ${ }^{26}$ Convocada a Assembleia Constituinte (1890-1891), ${ }^{27}$ Rui Barbosa, fascinado pela experiência constitucional dos Estados Unidos, ofereceu um anteprojeto em que pontificavam o liberalismo, o presidencialismo e o federalismo. Embora o projeto tenha sofrido alterações na Constituinte e, em certa medida, o texto final tenha-se afastado do constitucionalismo norte-americano, esses traços marcaram a Constituição de 1891.

Inicialmente, cabe observar que as ideias constitucionais adotadas nas estruturas textuais normativas se confrontavam, na prática constitucional, com o positivismo comteano, que influenciava a elite militar dirigente nos primeiros anos da República, compreendido em uma perspectiva que viabilizava a justificação de qualquer violação das normas constitucionais em nome da defesa da "ordem". ${ }^{28}$ Esse confronto entre ideias liberais conformadoras da textualização constitucional e ideias autoritárias da prática constitucional conduzida pelo Executivo militar, nos primeiros anos da República, já é um indício de descompasso e de complementaridade entre textualização e realização constitucional.

Com a Constituição de 1891, torna-se ainda mais problemática a relação entre texto constitucio- 
nal e realidade do processo de poder, se comparada com a experiência constitucional do Império. ${ }^{29}$ Amplia-se a declaração de direitos e liberdades individuais, assim como se afirma o princípio da "separação dos poderes" no documento constitucional, mas a estrutura social subjacente e a prática política dominante reproduzem-se, em grande medida, à margem do contorno textual-normativo da Constituição. A permanente deturpação ou violação da Constituição em todo o período em que ela esteve formalmente em vigor (1891-1930) (Pacheco, 1958 , pp. 240 ss.) pode ser apontada como o mais importante traço da realidade político-jurídica da Primeira República. Constituem expressões significativas da falta de concretização normativa do texto constitucional: a fraude eleitoral como regra do jogo político controlado pelas "oligarquias" locais; ${ }^{30}$ a degeneração do presidencialismo no chamado "neo-presidencialismo", ${ }^{31}$ principalmente através das declarações exorbitantes do estado de sítio (Barbosa, 1932-1934, vol. II, pp. 373ss.; vol. III, pp. 323ss.); a deformação do federalismo mediante a "política dos governadores" 32 e a decretação abusiva da intervenção federal nos Estados (idem, vol. V, p. 17).

Entre os críticos conservadores, adeptos de um Estado autoritário, corporativista e nacionalista, o problema da falta de concretização normativa do texto constitucional de 1891 foi denunciado como contradição entre "idealismo da Constituição" e "realidade nacional". ${ }^{33}$ Porém, em suas críticas ao "idealismo utópico" do legislador constituinte, a significação simbólica do documento constitucional não foi considerada com exatidão, mas, ao contrário, foi acentuada a ingenuidade de "suas boas intenções". ${ }^{34}$ Nesses termos, a Constituição seria expressão de ideias fora do lugar. Não pertencia à discussão se o chamado "idealismo utópico" só foi adotado no documento constitucional na medida em que a realização dos respectivos princípios ficou adiada para um futuro remoto, de tal maneira que o status quo não era ameaçado. Além do mais, não se pode excluir que a "Constituição nominalista" de 1891 atuava como constructo de identificação simbólica da experiência político-jurídica brasileira com a norte-americana, construindo-se a imagem de um Estado brasileiro tão "democrático" e "constitucional" como o seu modelo. No mínimo, a invocação retórica aos valores liberais e democráticos consagrados no documento constitucional funcionava como desencargo dos "donos do poder", transferida para a suposta "sociedade atrasada" a "responsabilidade" ou a "culpa" pelo desprezo à Constituição.

A questão, porém, não deve ser posta nos termos de uma alternativa entre idealismo liberal (iluminista, alienado) e realismo autoritário (autêntico, enraizado). As ideias do constitucionalismo liberal circulavam no âmbito dos setores civis de uma embrionária "classe média", ainda muito limitada entre minorias privilegiadas vinculadas principalmente aos latifúndios e massas subalternas ou excluídas no campo e na cidade. Rui Barbosa é uma expressão típica dessa nova "classe média" (Dantas, 1962a, pp. 24, 27 e 36-38). ${ }^{35}$ Não se pode negar que havia uma exacerbaçãao retórica em relação à Constituição norte-americana (assim como ocorrera com o constitucionalismo francês e o parlamentarismo inglês durante o Império), capaz de alimentar a ilusão simbólica de que o simples transplante do modelo constitucional dos Estados Unidos ofereceria uma solução adequada dos problemas sociais brasileiros. ${ }^{36}$ Nesse sentido, Oliveira Vianna (1939, p. 91) falava da "crença do poder transfigurador das fórmulas escritas". Entretanto, cabe observar que o próprio Barbosa não era totalmente acrítico em relação à possibilidade de transferência de instituições norte-americanas para a realidade brasileira mediante promulgação de Constituição ou legislação (Barbosa, 1932-1934, vol. I, p. 30). A questão reside no fato de que, no plano da semântica da sociedade mundial na virada do século XIX para o século XX, as ideias constitucionalistas circulavam e migravam sem compromisso com um ponto de origem. Barbosa era um jurista envolvido nessa discussão do seu tempo. O problema que se põe refere-se ao momento em que essas ideias pretendiam tomar forma no plano estrutural da normatização constitucional e, dessa maneira, influenciar a estabilização de expectativas normativas fundamentais à vida de Estados em contextos sociais tão diversos. Em verdade, a compreensão dessa questão exige que o debate vá além da dicotomia entre "idealismo" (alienante, estrangeiro) e "realismo" (autêntico, nacional) ou entre "país real" e "país oficial". Não se pode compreender a realidade político-jurídica do país senão como composta de "idealismo" e "realis- 
mo", em relação de tensão e complementaridade. Nesse sentido, cabe considerar a dinâmica de deslocamento das ideias (no nível semântico) em face das estruturas normativas e das operações da prática jurídico-política.

A semântica do constitucionalismo liberal, articulada nos termos da experiência norte-americana, foi incorporada ao plano das estruturas normativas mediante a textualização constitucional de 1891. Essa semântica, porém, era entrecortada por uma semântica local da autenticidade, que veio a encontrar expressão estrutural, mais tarde, na Constituição autoritária de 1937. Além disso, a textualização constitucional é dimensão tênue e pouco significativa, em si mesma, das estruturas normativo-jurídicas. As expectativas normativas eram pervadidas por critérios de sobreinclusão e subinclusão nos sistemas jurídico e político. ${ }^{37}$ Uma minoria privilegiada atuava à margem da Constituição, sem que os mecanismos sancionatórios respectivos tivessem qualquer significado prático relevante. Dessa situação não estava excluída a atuação dos órgãos governamentais. Nesse sentido, o próprio Rui Barbosa era enfático em seus comentários à Constituição: "Um dos flagelos que desgraçam hoje este país, são as chamadas oligarquias locais estaduais, que o Governo da União acoroçoa, explora, sustenta e agrava, servindo-se, para isso, já dos exércitos militares de mar e terra, já do exército civil, que o nosso inumerável funcionalismo lhe proporciona" (Barbosa, 1934, p. 17).

Essa prática dos sobreincluídos, localizados, por assim dizer, "acima" da Constituição, era inseparável, no período da Primeira República, da situação dos subincluídos ou excluídos por "baixo", que se encontravam aquém da Constituição. Estes já estavam excluídos pelas próprias determinações constitucionais, que estabelecia serem inalistáveis os analfabetos e os mendigos, parte majoritária da população. Entretanto, além desses dispositivos constitucionais, a situação de exclusão social de amplas parcelas dos indivíduos e grupos tornava as declarações de direitos e garantias individuais irrelevantes para eles: dependentes da satisfação inadiável de necessidades vitais, grande parte deles libertos formalmente da escravidão, viviam em relação de subalternidade perante senhores e patrôes ou como corpos socialmente insignificantes. ${ }^{38}$

As relações de subreinclusão e subinclusão atuavam como fator de bloqueio de uma concretização e efetivação constitucional. A Constituição não se concretizava de forma generalizada, mas de maneira seletiva e particularista, conforme a constelação concreta de interesses dos sobreincluídos. Não funcionava primariamente como horizonte jurídico dos detentores do poder, senão era usada, abusada e desusada em razão de condições fáticas e casuísticas das relações políticas de dominação. Em outras palavras, a concretização constitucional ficava fortemente condicionada e limitada pelas injunçōes arbitrárias dos "donos do poder". Dessa maneira, a Constituição implodia como horizonte reflexivo fundamental das práticas jurídicas e políticas.

Isso significaria que as ideias do constitucionalismo liberal individualista, então inspiradas principalmente pela experiência do presidencialismo e federalismo norte-americano, seriam "ideias fora do lugar"? No Estado brasileiro da Primeira República (1889-1930), topos político-jurídico territorialmente delimitado, essas ideias sofriam um deslocamento de sentido na relação entre política e direito enquanto sistemas funcionais precariamente diferenciados. Do ponto de vista estritamente jurídico-normativo, sua textualização constitucional tinha pouco significado estrutural para a estabilização generalizada de expectativas normativas no âmbito de uma concretização constitucional satisfatória. Essa questão estrutural, por sua vez, é inseparável do problema operativo, tendo em vista que as comunicações e as respectivas ações político-jurídicas se desviavam do modelo textual de Constituição. Entretanto, na perspectiva política, as ideias liberais incorporadas ao texto constitucional desempenhavam uma relevante função simbólica. E essa função era ambivalente. Por um lado, ela servia para certa autoilusão constitucional, no sentido de uma identificação retórica e "ideológica" do Estado brasileiro com a experiência constitucional dos Estados Unidos e também de Estados europeus da época. Por outro, o texto constitucional servia à crítica por parte da intelectualidade e da oposição a respeito das práticas políticas e jurídicas violadoras da Constituição. Em parte, essa crítica, conforme já adiantado, pugnava pelo Estado autoritário, contra 
o "idealismo utópico" e a favor do "idealismo orgânico", ${ }^{39}$ conforme a semântica de uma autenticidade nacional. Em parte, essa postura apontava por uma pretensão de concretização e efetivação constitucional. De incluir-se nessa segunda vertente, pode-se afirmar que Rui Barbosa, principal redator do projeto da Constituição de 1891, enfeixou a ambivalência da função político-simbólica das ideias liberais corporificadas no texto constitucional: a sua retórica liberal de enaltecimento da Constituição convivia com o seu discurso crítico da prática governamental. No âmbito dessa ambivalente função hipertroficamente simbólica do texto constitucional, que deu roupagem às ideias jurídico-políticas liberais nos termos da experiência norte-americana, não se atentava, porém, para o fato de que a concretização e a efetivação jurídico-normativa generalizada da Constituição pressuporiam rupturas radicais, para não usar o termo "revolucionárias", na estrutura da sociedade no Brasil da Primeira República. Isso porque, evidentemente, essa alternativa não estava no horizonte histórico de possibilidades do Brasil na sociedade mundial da época, fundada em forte assimetria econômica e social entre regiōes e países.

\section{Ao Código Civil de 1916}

Há uma íntima conexão entre a Constituição liberal de 1891 e a codificação civil que se afirmou em 1916. A articulação paradoxal entre ideias liberais individualistas, estruturas normativo-jurídicas com baixa força de concretização e estruturas sociais com forte potencial excludente desenvolve-se em um processo que se inicia com a constitucionalização formal e se solidifica com a codificação.

Em 1890, o governo provisório encarregou o jurista Antônio Coelho Rodrigues da elaboração de um Projeto de Código Civil, que, concluído em 1893 , foi rejeitado por comissão nomeada pelo governo e, posteriormente, embora tenha sido aprovado no Senado (1896), não teve andamento na Câmara dos Deputados (Brandão, 1980, p. 19; Pontes de Miranda, [1928] 1981, pp. 82-83). ${ }^{40}$ Em 1899, Clóvis Bevilaqua, então professor de legislação comparada na Faculdade de Direito do Recife, foi con- vidado pelo governo para elaborar um novo Projeto de Código Civil. Tendo iniciado sua elaboração em abril, já em novembro Bevilaqua concluiu o trabalho. O Projeto foi revisto por uma comissão constituída pelo governo e enviado à Câmara dos Deputados em 1900. Sob a relatoria de Sílvio Romero, ${ }^{41}$ foi aprovado na Câmara dos Deputados com várias alteraçōes, tendo sido remetido ao Senado em 1902. Sob a relatoria de Rui Barbosa, cujo parecer, apresentado em 3 abril de 1902, concentrou-se em restrições à formulação linguística e gramatical, sem considerar as questôes de fundo jurídico, ${ }^{42} \mathrm{o}$ Projeto ficou emperrado no Senado até 1912, quando passou a ser discutido na Câmara dos Deputados. Em ambas as casas do Congresso, o Projeto revisto pelo governo sofreu diversas alterações, só vindo a ser aprovado em dezembro de 1915 , com sanção e promulgação em $1^{\circ}$ de janeiro de 1916 e entrada em vigor em $1^{\circ}$ de janeiro de $1917 .{ }^{43}$

Embora, do ponto de vista filosófico, fortemente influenciado pelo evolucionismo e positivismo e, do ponto de vista jurídico, impregnado pela jurisprudência dos interesses (Ihering) e marcado por um certo "sociologismo jurídico" (Machado Neto, 1969, pp. 112ss.; Dantas, 1962c, pp. 84ss), Clóvis Bevilaqua propôs um código que correspondia basicamente ao modelo de codificação liberal do século XIX, ${ }^{44}$ nos termos da tradição conceitualista do direito. Não pretendeu apresentar, "como Freitas, uma obra original e revolucionária”, mas sim selecionar soluções encontradas nos projetos anteriores, nos códigos estrangeiros e no direito vigente no Brasil (Dantas, 1962c, p. 89). Apesar da postura liberal novecentista, o projeto de Bevilaqua (1899), em pontos fundamentais, mostrou-se menos insensível às transformaçôes sociais do século $\mathrm{XX}$ do que o Código Civil aprovado em 1916. Em dois aspectos, essa diferença pode ser verificada, a saber, na questão social e na questão da família e do gênero.

No que diz respeito à primeira, são esclarecedoras as observações de Santiago Dantas:

Bevilaqua não incorporara, por certo, ao Projeto primitivo soluçôes que pudessem representar a nova concepção jurídica das relações de trabalho, a exemplo do que fez o Código Civil alemão ao distinguir a locação de serviços do 
contrato de trabalho $(\$ 631)$, mas o seu tratamento da matéria era bem mais adiantado do que o resultante das alterações feitas no curso da revisão. Entre as normas por ele propostas, e excluídas do Código, figuravam o direito à percepção do salário no caso de impedimento transitório de trabalhar por motivo de doença (art. 1369), ou o dever de assistência médica ao trabalho doméstico (art. 137), a proibição do trabalho industrial ou das minas aos menores de 12 anos (art. 1381), a limitação a seis horas do tempo de trabalho de menores de 16 anos (art. 1382), o dever do empregador de eliminar as condições de insalubridade sob pena de responder por suas consequências (art. 1383) (idem, p. 90).

Rejeitados esses embriōes de legislação trabalhista, esta só veio a desenvolver-se a partir da década de 1930, sendo marco de sua fundação no Brasil a Consolidação das Leis Trabalhistas de 1940, permanecendo fora de sua proteção, por muito tempo, o trabalhador rural ${ }^{45}$ e o empregado doméstico, este até recentemente não incluído no regime do Fundo de Garantia por Tempo de Serviço, cujo papel principal foi o de substituir o regime de estabilidade dos trabalhadores e da indenização por tempo de serviço em caso de demissão sem justa causa. ${ }^{46}$

No que diz à questão da família e do gênero, embora Bevilaqua tenha tido uma posição radicalmente contrária ao divórcio, o qual considerava um recuo "da situação moral da monogamia para o regime de poligamia sucessiva" (Bevilaqua, 1906, p. 98), e seu projeto tenha sido rigoroso em definir o marido como chefe da sociedade conjugal (art. 272), sua posição foi contrária à incapacidade relativa da mulher casada para amplos atos da vida civil (idem, pp. 93-96), solução adotada no Código Civil (arts. 240-247 e 252) e só superada mediante as alteraçôes introduzidas pela Lei no 4.121, de 27 de agosto 1962. ${ }^{47} \mathrm{O}$ art. 279 do Projeto de Bevilaqua firmava que, pelo casamento, "torna-se a mulher companheira e sócia do marido", diferentemente do Código Civil, o qual, na redação originária, dispunha assumir a mulher, pelo casamento, "a condição de sua companheira, consorte e auxiliar no encargo doméstico". Nessa perspectiva, embo- ra manifestasse as concepções de sua época sobre as diferenças entre o homem e a mulher, Bevilaqua apontava, ao contrário do Código Civil, para uma solução em direção à igualdade entre os gêneros, conforme suas próprias palavras: "Desenvolvendo o mesmo pensamento, procurando atender às justas aspirações femininas e querendo fazer do casamento uma sociedade igualitária, embora sob a direção do marido, concedeu o Projeto maior soma de direitos, maior liberdade de ação à mulher casada do que o direito que atualmente vigora entre nós" (idem, pp. 93-94).

Ele acrescentava, então, que "o Projeto tencionou reconhecer na mulher um ser igual ao homem, mas sem desviá-la das funções que lhe indica a própria natureza, racionalmente interpretada" (idem, p. 95). Ponderava, porém, ter "o autor do Projeto convicção de que foi, neste ponto, tão liberal quanto lhe era permitido ser" (idem, p. 96).

É interessante acrescentar que, ainda a respeito da questão da família, o Projeto de Bevilaqua foi bem mais favorável à situação jurídica dos então chamados "filhos ilegítimos" do que a solução adotada no Código Civil (Bevilaqua, 1906, pp. 99105), distanciando-se das concepções morais e religiosas dominantes à sua época no Brasil. ${ }^{48}$

Em relação às disposições concernentes à família e ao gênero, juristas interessados em sua localização histórica atribuíram ao Código Civil, de forma mais contundente do que ao projeto originário, traços antiliberais ou, no mínimo, não liberais. Segundo Pontes de Miranda ([1928] 1981, p. 443), vários dispositivos do Código "denunciam a preponderância do círculo de família, ainda patriarcal", constituindo "um direito mais preocupado com o círculo social da família do que com os círculos sociais da nação, das classes". Essa posição foi corroborada por Orlando Gomes (1958, pp. 21-35), que sublinhou a "influência do privatismo doméstico" em sua elaboração. Nesse particular, foram apontados dispositivos referentes à indissolubilidade do vínculo matrimonial, à comunhão universal de bens e à disciplina do regime optativo de separação, à tutela e à curatela, assim como ao direito hereditário, enfatizando-se, por exemplo, o direito incondicionado do testador "de gravar os bens dos herdeiros, mesmo os que constituem a legítima, com a cláusula de inalienabilidade 
vitalícia”, tudo isso em favor da posição imensamente privilegiada do marido como chefe da sociedade conjugal (idem, pp. 24-28). Especialmente em relação à questão do gênero, o art. 236, que prescrevia serem válidas, sem o consentimento da mulher, "doações nupciais feitas às filhas e as doaçōes feitas aos filhos por ocasião de se casarem, ou estabelecerem economia separada", refletiria, conforme Pontes de Miranda ([1928] 1981, p. 449), "a precariedade da situação da mulher brasileira": "Devia ter cogitado da filha que, não se casando, quer, no entanto, estabelecer vida autônoma, 'economia separada'”.

Essa forma de considerar a preponderância do círculo familiar foi associada à afetividade, tolerância e benevolência jurídica (idem, pp. 441ss.). O próprio elaborador do projeto originário, Clóvis Bevilaqua, sustentou que "o direito civil brasileiro pode considerar-se um 'direito afetivo' - porque muitas de suas disposições mais características foram tomadas por motivo de sentimento", acrescentando que "dois princípios gerais se apuram, como energias propulsivas ou inspiradora de nossa vida jurídica (legislação, doutrina e jurisprudência): 'o sentimento de liberdade' e 'os impulsos idealistas'” (Bevilaqua, [1922] 1975, p. 193). Essa sugestão da existência de uma "jurisprudência dos sentimentos", a prevalecer no Brasil, mereceu restrições de Pontes de Miranda quanto aos seus elementos "despóticos", mas este a vinculava a uma "benevolência jurídica", que era, por um lado, criticada com base em argumentos racialistas e, por outro, confundida com "'liberalismo" excessivo" ([1928] 1981, pp. 444ss). ${ }^{49}$ Em verdade, expressões como "afetivismo" e "benevolência" atuavam antes de maneira ideologicamente simplificadora, desviando a atenção de problemas referentes a assimetrias, a relações de dependências e de favores, assim como à condição ainda patriarcal no ambiente familiar. E mesmo supondo-se a presença de uma "afetividade" como fator de produção jurídica e aplicação do direito civil, esse traço teria que ser definido como algo contrário ao liberalismo individualista e considerado, sobretudo, na sua dimensão opressora, uma vez que estaria relacionado com o poder arbitrário dos privilegiados socialmente, em detrimento dos mais frágeis. Daí por que, em vez de levar a sério expressões como "direito afetivo" e "benevolência jurídica", é mais oportuno relacionar a influência do chamado "privatismo doméstico" com a persistência de uma base rural nas primeiras décadas da República, que, apesar da abolição da escravatura, mantinha ainda traços de exclusão, privilégios e relações de dependência semelhantes à estrutura social do Império.

Portanto, a questão do gênero e da família relaciona-se com a "questão social". A esse respeito, Orlando Gomes (1958, pp. 51ss.) procurou salientar que o Código Civil não adotou nenhuma disposição referente aos direitos sociais e às relações trabalhistas, desconsiderando os desenvolvimentos que vinham ocorrendo na Europa. O Código ter-se-ia mantido fiel ao individualismo jurídico do século XIX. De fato, como já adiantado, em matéria de acidente de trabalho, proteção ao trabalhador em caso de doença, proibição do trabalho dos menores, limitação da jornada de trabalho, proteção do empregado em condiçôes laborais insalubres etc., nada constava no Código. As diversas tentativas que foram apresentadas nos debates parlamentares para elementos mínimos de direito social fracassaram (idem, ibidem).

Conforme Orlando Gomes, o próprio autor do projeto originário, Clóvis Bevilaqua, "assumia, de modo nítido e firme, uma posição categórica contra inovaçôes de fundo social" (idem, p. 57). Em sua defesa do projeto, Bevilaqua realmente mostrava desconfiança por aquilo que definia como "socialismo", inclusive no sentido de reconhecimento de direitos em termos do Estado social, que, segundo ele, poderia "resvalar no socialismo absorvente e aniquilador dos estímulos individuais" (Bevilaqua, 1906, p. 41). ${ }^{50}$ Alegava, então, que o "direito privado social não pode ser outra coisa mais do que o equilíbrio dos interesses do indivíduo e da sociedade", sustentando que, fora desses parâmetros, as reformas "serão subversivas" (idem, p. 40). Entretanto, cabe considerar que, no contexto social dos atores envolvidos na elaboração, o individualismo que prevaleceu no Código foi muito além dos cuidados de Bevilaqua com o que "ele contém de exageradamente egoístico e desorganizador” (idem, p. 41). O Código não teria apagado, nas palavras do redator do projeto, "a nódoa de burguesismo que, por igual, deslustra os códigos civis imperantes" (idem, p. 40).

Essa situação manifestou-se particularmente nas discussões que se travaram em torno da locação de 
serviços na Comissão Especial da Câmara dos Deputados (Gomes, 1958, pp. 58ss.). A concepção de uma ampla autonomia da vontade impediu a inclusão de qualquer distinção entre contrato de locação de serviços celebrado no âmbito da autonomia privada e contrato de trabalho. Nem os mais rudimentares elementos de proteção do trabalhador previstos no projeto originário de Bevilaqua foram admitidos. Nesse "individualismo jurídico infenso a toda regulamentação legislativa do trabalho" (idem, p. 61), Pontes de Miranda via um direito mais preocupado "com certo capitalismo indisfarçado, porém ingenuamente convencido da sua função de consolidação e justiça social" ([1928] 1981, p. 443). Por sua vez, segundo Orlando Gomes, a "mentalidade dominante na época transfundiu-se com tanta objetividade nas regras codificadas no capítulo da locação de serviços, que nenhum a traduz com maior nitidez" (Gomes, 1958, p. 66). Entretanto, esse tipo de enfoque superestimava a relação entre o substrato social e o texto legal, sem considerar os limites da força normativa deste.

Nesse particular, além de considerar as condiçôes particulares das ideias liberais de codificação no contexto do chamado "privatismo doméstico" e a opção ainda por um liberalismo individualista dominante na Europa do século XIX, cumpre observar, em primeiro plano, o significado prático da codificação no processo de concretização jurídica e efetivação do direito civil. Como se posicionava um código extremamente liberal nas matérias das relaçôes de trabalho perante uma sociedade ainda de base rural, na qual o latifúndio monocultor era a principal mola propulsora da economia e da vida social? Entre os senhores rurais (associados ao setor mercantil de exportação e importação) e a massa dos deles dependentes e dos indigentes, havia uma ínfima "classe média" urbana em formação. Nesse contexto, enquanto os proprietários de terra podiam "resguardar-se de investidas contra seus interesses fundamentais", o regime de "franquias liberais aproveitava, tão somente, a um reduzido número, sendo estranho à grande maioria da população miserável e inculta” (idem, p. 46). Tratava-se de relaçôes de sobreinclusão e subinclusão, ou seja, entre, respectivamente, os situados "acima" e os localizados "abaixo" do direito civil do ponto de vista sociojurídico. Abolida a escravidão, a maioria da população era constituída, nas palavras de Sílvio Romero, secundado por Orlando Gomes, por "pobres da inércia”, não por trabalhadores rurais e fabris capazes de reivindicar direitos (Romero, 1894, p. xxxiv; Gomes, 1958, pp. 39-40). Sem acesso a direitos civis elementares, esses miseráveis, a perambular no campo e nas cidades, conseguiam, no máximo, realizar serviços esporádicos, engajar-se em relaçôes informais de trabalho ou incorporar-se como empregado doméstico, sempre à margem do direito.

A respeito do contrato de locação de serviço, Pontes de Miranda, abstraída aqui a explicação racialista que dava ao problema, ${ }^{51}$ foi atento à incompatibilidade entre o individualismo liberal do Código e as "relações de criadagem": "o criado brasileiro não reivindicava, - como que continuou a servir, liberto, ao antigo senhor; as tentativas de modernizar a locação de serviços eram infrutíferas, porque esbarravam na dupla indiferença, do patrão e do empregado doméstico" ([1928] 1981, pp. 445446). Sem dúvida, uma dupla indiferença fundada na extrema assimetria das posiçôes, que tornava os primeiros imunes a deveres e os segundo, carentes de direitos. Uma situação que, apesar de todas as transformaçōes do direito do trabalho no Brasil, ainda persiste, em parte, nas relações de prestação de serviço doméstico que abundam no país.

Não se pode negar inteiramente que a promulgação de um código civil liberal individualista em um contexto de extremas desigualdades sociais, com relaçôes de trabalho ainda impregnadas pelo escravismo, pode ser interpretada como "cópia", "importação" ou "transplante" de direito estrangeiro, sem compromisso com a realidade social do país, com "inevitáveis deformaçôes" (Gomes, 1958, p. 45). É nessa perspectiva que se deve compreender a afirmação de Pontes de Miranda: "O Código Civil Brasileiro, pelo que deve a Clóvis Bevilaqua, é uma codificação para as Faculdades de Direito, mais do que para a vida" ([1928] 1981, pp. 86-87). Por sua vez, Orlando Gomes, ao mesmo tempo que se referia ao transplante de "instituições alienígenas, que nessas regiōes [de povos mais adiantados] começavam a murchar", afirmava que o Código "se antecipa à realidade", "apresentando-se como aproximação da realidade futura" (1958, pp. 43 e 72). Essa ambivalência sugere que não se tratava simplesmente de "transplante", "importação" ou "cópia" de artefatos institucionais. 
A codificação privada na segunda década do século XX deve ser compreendida no âmbito da abolição da escravatura e da constitucionalização liberal decorrente da proclamação da República. Também aqui, as ideias liberais do direito privado individualista eram entrecortadas pelas condições locais, tanto no plano da estrutura dos textos normativos quanto pela prática jurídica. A semântica jurídica liberal da sociedade mundial era não apenas entrecortada por ideias antiliberais ou não liberais dos juristas, mas também por estruturas sociais incompatíveis com o individualismo liberal. Isso repercutiu no próprio texto do código, especialmente no tratamento do direito de família. Portanto, no plano das estruturas jurídicas, a institucionalização mediante produção textual já implicava certo deslocamento das ideias liberais de codificação. Entretanto, parece-me que a questão maior diz respeito aos limites da concretização normativo-jurídica do Código no contexto social adverso. Como se apresenta o individualismo liberal para relações de dependência desenvolvidas no âmbito de redes estabilizadoras de expectativas de trocas, favores, prestaçōes recíprocas, lealdades, suprimento de necessidades inadiáveis etc., à margem do direito civil codificado? Nessas condiçôes, seu sentido e suas funções são deslocados.

Isso não significa, porém, irrelevância social da codificação civil fundada no liberalismo individualista. O baixo teor da força normativo-jurídica do Código conjugava-se com a sua função político-simbólica, que, assim como a da Constituição liberal, era ambivalente: por um lado, construía uma autoilusão da codificação como expressão da emancipação das relações civis no Brasil, que se aproximaria da experiência codificadora na Europa; por outro, a invocação do Código servia à crítica às práticas jurídicas e políticas desenvolvidas à sua margem. Nos termos dessa ambivalência, um deslocamento de sua plena efetivação para um futuro incerto impregnava o debate jurídico e político em torno do Código. Não se considerava, porém, que a concretização jurídico-normativa satisfatória do Código Civil pressuporia transformações radicais nas estruturas da sociedade no Brasil do início do século XX, uma alternativa que também não se apresentava no horizonte histórico de possibilidades do Brasil na sociedade mundial da época.
Tratar-se-ia de ideias fora do lugar? Parece-me que antes caberia falar de ideias em outro lugar, entre tantos lugares da sociedade mundial. Mas, paradoxalmente, como as ideias liberais de codificação faziam parte da sociedade mundial, não poderíamos dizer que são ideias no mesmo lugar? É esse paradoxo entre mundial e local ou regional que alimenta a reprodução de ideias políticas e jurídicas, ao menos enquanto houver Estados como organizaçôes territorialmente delimitadas. Ideias migrantes em uma unitas multiplex.

\section{Observações finais}

As questôes aqui tratadas a respeito da função e do sentido da constitucionalização liberal de 1891 e da codificação do direito civil de 1916, impregnadas de ideias liberais que vinham se firmando na Europa e nos Estados Unidos desde os fins do século XVIII, não configuram fenômenos isolados no desenvolvimento de instituições e ideias políticas e jurídicas no Brasil. Há uma persistência de variáveis similares no tocante ao deslocamento de ideias e à transmutação de instituições na experiência jurídica do século XX, constituindo problemas que ainda perduram - evidentemente, em medida e de maneira bem diversas - até hoje.

$\mathrm{Na}$ própria presença de um pensamento jurídico "crítico", no sentido de um Estado social ou mesmo socialista, nas décadas de 1920 e 1930, recolocavam-se os mesmos problemas: as ideias social-democráticas, embora adotadas na Constituição de 1934, tinham pouco significado para a maioria da população; e as ideias autoritárias da Constituição de 1937, além de não serem tão "autenticamente nacionais" como sustentavam seus defensores ${ }^{52}$ tiveram sua eficácia jurídica suspensa durante todo o período do Estado Novo (19371945), por força de uma disposição transitória (art. 187)..$^{53}$ Cumpre insistir que a busca desse pensamento "crítico" por um "país real", "profundo", em contraposição a ideias alienígenas, não era nada de novo, não podendo, de maneira nenhuma, ser vinculada à semana de Arte Moderna de $1922 .{ }^{54}$ Essa questão de um "país real” em oposição a um "país oficial" ou "legal" vinha sendo discutida desde a se- 
gunda metade do século XIX. O que mudava era o conteúdo do debate, cujo foco passava a ser a adequação das ideias social-democráticas, socialistas e fascistas ao contexto jurídico-político brasileiro. Essas ideias não eram, porém, nem menos, nem mais autenticamente brasileiras do que o liberalismo individualista que dominara anteriormente. Em ambos os casos, tratava-se de ideias em outro lugar $n a$ sociedade mundial.

Parece-me que a migração ou o deslocamento de ideias liberais individualistas orientadas para a constitucionalização e a codificação não deve ser compreendida, de forma genérica, nos termos de relaçôes simétricas na sociedade mundial. Ou seja, não basta dizer que elas estavam "no ar" ${ }^{55}$ Embora seja impertinente tratar o tema apenas em busca de "influências causais" (Lopes e Garcia Neto, 2009, p. 106), não se podem negar assimetrias na circulação dessas (e outras) ideias jurídico-políticas na sociedade mundial, ao deslocarem-se entre os seus diversos Estados. ${ }^{56}$ Em relação ao período pós-colonial latino-americano, desconhecer que havia centros predominantemente irradiadores e periferias primariamente receptoras ou apropriadoras de ideias liberais significa deixar de lado aspectos cruciais da experiência jurídica e política dos respectivos países. ${ }^{57}$ A respeito do Brasil, é incontroversa a presença de certo colonialismo cultural (Montoro, 1973). Nesse sentido, não se deve excluir inteiramente os termos "importação", "transplante", "cópia", "imitação" etc., nem mesmo as noçōes de "deformação" de ideias e de "impureza" de teorias (Medina, 2008).

Entretanto, isso não quer dizer que se trata de "ideias fora do lugar", pois, entrecortadas por semânticas locais e condicionadas por estruturas da sociedade mundial no respectivo Estado, elas têm um sentido e desempenham funções tanto no âmbito das instituiçōes jurídicas e políticas quanto das práticas sociais. Nesse particular, corporificadas no plano institucional da textualização constitucional e legal, as ideias liberais, já entrecruzadas por exigências políticas e jurídicas locais irrenunciáveis, exerciam uma função primariamente simbólica, em detrimento de sua força normativo-jurídica. E a função simbólica serve, ambivalentemente, tanto à negação dos direitos quanto à luta por sua efetivação e ampliação. Em outra perspectiva, Schwarz - a rigor, em ensaio de revisão de sua própria formulação originária sobre "ideias fora do lugar" - afirma, ainda em relação ao Brasil imperial, algo que poderia aproximar-se dessa formulação:

Ora, nas ex-colônias, assentadas sobre o trabalho forçado, o liberalismo não descreve o curso real das coisas - e nesse sentido ele é uma ideia fora do lugar. Não impede contudo que ele tenha outras funçôes. Por exemplo, ele permite às elites falarem a língua mais adiantada do tempo, sem prejuízo de em casa se beneficiarem das vantagens do trabalho escravo. Menos hipocritamente, ele pode ser um ideal de igualdade perante a lei, pelo qual os dependentes e os escravos lutam. A gama de suas funçóes inclui a utopia, o objetivo político real, o ornamento de classe e o puro cinismo, mas exclui a descrição verossimil do cotidiano, que na Europa the dá a dignidade realista (Schwarz, 2012, pp. 170-171)..$^{58}$

Não obstante, parece-me que deve ser afastada, definitivamente, a concepção de "ideias fora do lugar" e o seu corolário, a falta de descrição da realidade. Em primeiro lugar, cabe ponderar que as ideias liberais de cunho constitucional ou jurídico estavam relacionadas com a dimensão normativa das estruturas sociais, não tendo função primariamente descritiva. No domínio dos direitos, o problema central não é, portanto, de descrição da "realidade". Em segundo lugar, no âmbito jurídico da constitucionalização e codificação, não cabe distinguir entre o "legal" ou "oficial" e o "real". A ineficácia do "legal" ou a distância do "oficial" em relação ao "povo", ou melhor, à maioria da população, faz parte da "realidade" político-jurídica, implicando práticas cotidianas. Por conseguinte - insisto -, em vez de "ideias fora do lugar", mais adequado seria falar que a ideias liberais assumiram diferentes funçōes nos diversos lugares político-jurídicos estatalmente organizados, mas elas pertencem à semântica da sociedade mundial, lugar de sua circulação. Daí por que a conclusão: as ideias liberais incorporadas à Constituição brasileira de 1891 e ao Código Civil brasileiro de 1916 eram, paradoxalmente, ideias em outro lugar (a sociedade no âmbito do Estado brasileiro) e no mesmo lugar (a sociedade mundial). 


\section{Notas}

1 Não me parece adequado, portanto, relacionar, originariamente, essa contraposição de um "país real” a um "país oficial" - também expressa na busca do "Brasil profundo" - ao movimento artístico e literário que se manifesta na Semana de Arte Moderna, ocorrida em São Paulo, em 1922, com ênfase em Mário de Andrade, e associar a referida dicotomia à adoção de ideias democrático-sociais, socialistas ou fascistas nas décadas de 1920 e 1930 no Brasil, como sugerem Lopes e Garcia Neto (2009, p. 27). Da mesma maneira, não cabe invocar a referência análoga à "distância entre o país legal e o país real" para explicar a emergência dessas ideias no referido período, muito menos vinculá-la à diferença do realismo americano entre law in books e law in action (idem, pp. 15 e 21-22) - esses autores retiraram tal referência ao realismo americano na edição definitiva, em espanhol, do referido artigo (cf. Lopes e Garcia Neto, 2011, pp. 125-126). Trata-se, como expresso por Machado de Assis, de um debate já presente no século XIX. Cf. também infra nota 3.

2 Esse trecho, ao contrário do que se pode inferir de Schwarz ([1977] 2000, p. 11), ao sustentar que o argumento de um panfleto liberal contemporâneo de Machado de Assis "põe fora o Brasil do sistema da ciência", sugere que estaria fora do sistema da ciência não o "país real", mas o "país oficial".

3 Nesse contexto, critica a ideia de que o poder neutro (conforme a noção de "poder real" na formulação de Constant, [1815] 1957, pp. 1078ss.; 1872, pp. 177 ss.) teria passado "rapidamente dos livros aos fatos": "A simples cópia de um princípio teórico em um artigo de Constituição não quer dizer que se tenha realizado ideia alguma. Isto é apenas passar de um livro para outro livro, sem que deixe de ficar em estado de pura teoria” (Barreto, [1871] 2000, p. 395).

4 A essa formulação associa-se a afirmação de Sílvio Romero, com base no positivismo e no evolucionismo então em voga: "É certo que os primitivos habitantes do país não ultrapassaram os últimos degraus da selvageria; é exato ainda que a nossa atual civilização é toda impregnada de barbarismo. Só os patriotas desajuizados poderão contestá-lo” (Romero, [1888] 1960, p. 83). Barreto, porém, fazia ressalvas em sua avaliação negativa da experiência política brasileira: "Já se vê que não é somente o lado bom, mas também o lado mau do governo inglês, igualmente indispensável para a conservação e harmonia do todo, que não pode ser transmitido a outro qualquer país" (Barreto, [1871] 2000, p. 417).
5 Embora, em ensaio posterior, Schwarz (2012) procure afastar-se enfaticamente dessa autocompreensão, o seu consagrado texto é ambivalente a esse respeito, pois ele mesmo utiliza a expressão "impropriedade de nosso pensamento" ([1977] 2000, p. 13), sublinhando que "o nosso discurso impróprio era oco também quando usado propriamente" (p. 21), para arrematar: "Ao longo de sua reprodução social, incansavelmente o Brasil põe e repõe ideias europeias, sempre em sentido impróprio" (p. 29). Voltarei ao tema nas observações finais.

6 Para um panorama, ver Santiago (2002). Nesse contexto teórico, insiste-se ainda em falar de sociedade brasileira e discutir sobre sociedades boas e más (cf., por exemplo, Villas Bôas Filho, 2009, p. 337). Em um rasgo de desinformação e irresponsabilidade acadêmicas, Jessé Souza pretende enquadrar-me entre os "intérpretes do Brasil" na busca de uma singularidade brasileira ou latino-americana, atribuindo a mim e também a Niklas Luhmann uma postura "culturalista” e imputando-nos, em uma deformação gritante de nossas obras, "racismo mal disfarçado em 'culturalismo' das teorias da modernização tradicional - que substancializam e 'essencializam' supostas heranças culturais como até cem anos atrás se 'essencializavam' supostas diferenças raciais" (Souza, 2013, p. 153). Além disso, apõe à minha obra apocrifamente a expressão "sociedades avançadas" (idem, p. 167). Souza aponta para um artigo no qual me referia especificamente ao caso latino-americano (Neves, 2012). É claro que, quando falo de "caso", no contexto de minha obra, estou a falar de algo próximo a um exemplo, no escopo de um espectro conceitual mais abarcante. Minha obra é inundada de passagens em que rejeito a noção de singularidade da experiência brasileira ou latino-americana (o Brasil não existe como sociedade no modelo da teoria dos sistemas), ainda mais se isso implica uma noção de unidade ou herança cultural (por exemplo, Neves, 1992, pp. 177-178, distanciando-me de Faoro, [1958] 1985, p. 133; Neves, 1994, pp. 269270, nota 8, distanciando-me de DaMatta, 1991) ou a noção de "sociedades avançadas" levada a cabo pelas teorias "clássicas" da modernização (enfaticamente, Neves, 1992, pp. 74-76). Antes estudo problemas de assimetrias estruturais na sociedade mundial (moderna), que são dinâmicas e contingentes nos termos da teoria dos sistemas, não tendo nada de "essencial". Seria de supor-se que o açodado crítico estava ciente disso, pois tomou emprestado o meu argumento sobre subcidadania na modernidade periférica para opor-se ao culturalismo que atribui a Roberto DaMatta, dan- 
do os créditos, em artigo do passado (Souza, 2000, p. 147); porém, estranhamente, eximiu-se, mais tarde, de qualquer referência aos meus trabalhos no livro em que utilizou essas expressões no próprio título (2003). Além de tudo, é o próprio Souza quem, em verdade, fala de "singularidade brasileira" (2003, pp. 93ss.) e mesmo de "singularidade cultural brasileira" (2000, pp. 128ss.). Ao contrário, Luhmann, ironicamente, afirma que "o conceito 'cultura" constitui "um dos piores conceitos que já foram construídos" (1995a, p. 398). E, quando o admite, é com a seguinte reserva: "O conceito 'cultura' [...] observa a si mesmo e tudo o que cai sob sua compreensão como contingente. [...] Daí que a semântica da cultura cobre tudo o que se pode comunicar com a contingência. Libera-se de qualquer tipo de sentido necessário [...]. Toda pretensão de autenticidade retrocede como algo incomunicável ou é tratada como capricho de determinadas pessoas ou grupos" (1995b, pp. 48 e 51, grifo meu).

7 Quando se parte do pressuposto teórico-sistêmico fundamental de que a sociedade moderna constituiu uma sociedade mundial, pensa-se em um contexto comunicacional unitário que, como sistema social abrangente, está diferenciado primariamente em diversos subsistemas funcionais (Luhmann, 1975; 1993, pp. 571ss.; 1997, pp. 145-171; Stichweh, 2000). Isso, contudo, não exclui uma diferenciação segmentária secundária em Estados como organizaçôes territoriais estritamente delimitadas, válida tanto para o sistema político quanto para o sistema jurídico (Luhmann, 1998, pp. 375ss.; 2000, pp. 222ss.; 1993, p. 582). Nesse contexto, a teoria dos sistemas de Luhmann, apesar de toda a ênfase no conceito de uma sociedade (mundial) única, não é indiferente aos problemas que, como consequência do desenvolvimento assimétrico dessa sociedade, emergem em diversas regiōes do globo (cf. Luhmann 1986, p. 168; 1993, p. 572; Neves, 2006).

8 Cf. Luhmann (1997, pp. 158-159), com objeções à concepção de capitalismo como "sistema mundial", proposta por Wallerstein (2006).

9 Os trechos citados de obras em língua estrangeira foram traduzidos por mim para o português.

10 "Se o nível de complexidade da sociedade modifica-se, a semântica orientadora do vivenciar e agir precisa adequar-se a ele, porque, senão, ela perde a conexão com a realidade" (Luhmann, 1980, p. 22).

11 Em temática similar, embora com outras implicações a partir da obra de Luhmann e de meus trabalhos críticos a respeito dela, ver Ribeiro (2013).
12 Cf. Neves, 1992, pp. 116-121, com ampla referência bibliográfica.

13 "XVIII. Organizar-se-á quanto antes um Código Civil, e Criminal, fundado nas sólidas bases da Justiça, e Equidade."

14 "Art. 83 - Continuam em vigor, enquanto não revogadas, as leis do antigo regime no que explícita ou implicitamente não forem contrárias ao sistema do Governo firmado pela Constituição e aos princípios nela consagrados." A respeito desse dispositivo constitucional, esclarece Pontes de Miranda (1981 [1928], p. 43): "Em virtude da revogação implícita não podiam perdurar, e assim foi entendido: a servidão de pena, a morte civil, a diferença entre filhos de nobre e os filhos de peão quanto ao direito de sucessões, etc.".

15 Este autor acrescenta: "Da mesma maneira, as alegações dos advogados reduziam-se, pela maior parte, à acumulação, tão extensa quanto fastidiosa, de remissões, quase sempre copiadas, e muitas vezes impróprias" (p. 44).

16 Entretanto, essa formulação de Pontes de Miranda deve ser relativizada no que diz respeito ao que realmente veio a ser "consolidado", pois a Consolidação também teve caráter inovador para a ordem jurídica brasileira do Império (cf. Fonseca, 2012, pp. 26ss.).

17 Após a primeira edição oficial em 1857 , a segunda edição em 1865 e a terceira em 1876, foi publicada a quarta edição, com os Aditamentos em resposta às críticas, em 1877, tendo sido publicada, em 1915, a quinta edição, acrescida das novas leis e decretos editados até 1913 (cf. Mártinez Paz, 1927, p. xxix). Para a análise do alcance e do conteúdo da Consolidação, ver Meira (1983, pp. 111 ss.).

18 Cf. Surgik (1988), Meira (1983, pp. 113-114), Mercadante (1980, p. 188). Observe-se que a ideia de um "código negro" não era nenhuma novidade, tendo sido adotada na França em 1685 por Luís XIV no Édito chamado Le Code Noir (https://archive.org/ stream/lecodenoirouedi00fran\#page/n5/mode/2up), para vigorar apenas em colônias da França (a respeito, ver Sala-Molins, 1987; Mignot, 2007; Richard, 2010). A grande diferença é que, no contexto imperial brasileiro, a proposta de Teixeira Freitas era para a sua adoção e vigência em um país (ao menos jurídico-formalmente) independente.

19 Estranhamente, em seus comentários ao art. 6º, inciso I, da Constituição imperial, nem Bueno (1857, pp. 450-3), nem Sousa (1867, pp. 40-53), nem Rodrigues (1863, p. 10) faz qualquer referência a essa questão. 
20 Cf. Pontes de Miranda ([1928] 1981, p. 81); Gomes (1958, p. 19); Nabuco ([1897-1899] 1997, pp. 1054ss.); Meira (1983, pp. 186ss.). O Esboço (Freitas, 1983) foi publicado originariamente em 1864.

21 Cf. Nabuco ([1897-1899] 1997, p. 1062); Meira (1983, pp. 361-362); Gomes (1958, p. 19, nota 18). Entretanto, a proposta havia sido acatada pela Seção de Justiça do Conselho de Estado (Nabuco, [18971899] 1997, pp. 1060-1061; Mártinez Paz, 1927, p. xix; Meira, 1983, pp. 356-358; Alves, 2003, p. 4).

22 A carta encontra-se na íntegra em Meira (1983, pp. 352-356).

23 Sobre a repercussão da obra de Teixeira de Freitas em outros países (inclusive europeus), ver Meira (1983, pp. 387ss.). Na Argentina, Dalmacio Vélez Sársfield, ao apresentar ao Ministro da Justiça o primeiro livro do Projeto de Código Civil, em 21 de junho de 1865, declarou que se serviu de diversos códigos estrangeiros, "y sobretodo, del Proyecto de Código Civil que está trabajando para el Brasil el Sr. Freitas, del cual he tomado muchíssimos artículos" (apud Meira, 1983, p. 288). Cf. Mercadante (1980, p. 194, nota 24); Pontes de Miranda ([1928] 1981, p. 80). Por sua vez, o senador Carlos Serrey declarou que o Código Civil argentino "consituye un titulo de honor para el doctor Vélez Sársfield e para el jurisconsulto brasileño Freitas, su guia principal" (apud Pontes de Miranda, ibidem). A esse respeito, ver, em detalhes, Meira (1983, pp. 267ss.), Mártinez Paz (1927, espec. pp. xxxii-xxxiii e xlv-xlix), Levaggi (1988).

24 Além do Esboço de Teixeira de Freitas, houve outras duas tentativas de codificação civil no Império, também sem sucesso: os projetos de Nabuco de Araújo (Nabuco, [1897-1899] 1997, pp. 10621074) e de Felício dos Santos (Pontes de Miranda, [1928] 1981, p. 82).

25 Não se desconhece aqui que a semântica econômica liberal da sociedade mundial era entrecortada pelo escravismo do Império brasileiro, não sendo de rejeitar-se, nesse particular, a asserção de Bosi (1992, p. 195): "O par formalmente dissonante, escravismo-liberalismo, foi, no caso brasileiro pelo menos, apenas um paradoxo verbal”. Entretanto, cumpre distinguir, como já sustentado na introdução, entre a semântica "factual" do liberalismo, fundada diretamente nas estruturas (expectativas cognitivas) do capitalismo mundial, e a semântica "contrafactual" do idealismo jurídico liberal - na qual, em certa medida, o Esboço assentava-se -, relacionada imediatamente com as estruturas político-jurídicas (expectativas normativas).
Quanto a essa última semântica, pode-se afirmar a existência uma tensão paradoxal entre o liberalismo do Esboço e o escravismo imperial. A esse respeito, o próprio Bosi (ibidem) admite que o conteúdo do par "escravismo-liberalismo" poderia pôr-se "como contradição real se se atribuísse ao segundo termo, liberalismo, um conteúdo pleno e concreto, equivalente à ideologia burguesa do trabalho livre que se afirmou ao longo da revolução industrial europeia”. Entretanto, Bosi não admitia as diferenças da qual partimos, que implicam paradoxos, pois estava vinculado a uma ontologia dialética da totalidade (daí por que fala, antes, de "contradição"). Além do mais, não se pode desconhecer que o desenvolvimento do liberalismo nas metrópoles, tanto do ponto de vista das expectativas cognitivas e normativas (estrutura) quanto da semântica, estava relacionado, paradoxalmente, com a escravidão nas colônias. Uma das dimensões semânticas deste paradoxo apresenta-se no silêncio dos autores iluministas em relação ao Código Negro e, em geral, à escravidão nas colônias (cf. Kolle, 1991; Sala-Molins, 1987, pp. 205ss.).

26 Segundo a famosa formulação de Aristides Lobo: " $O$ povo assistiu àquele acontecimento bestificado, espantado, surpreso, sem saber o que ele significava. Muitos acreditavam sinceramente estar assistindo a uma parada" (apud Maximiliano, 1948, p. 105).

27 Para uma detalhada exposição das sessões da Constituinte e das discussões nela travadas, fortemente impregnadas pelo constitucionalismo norte-americano, ver Roure (1918-1920). Cf. infra nota 36.

28 Sobre a deformação do positivismo de Augusto Comte na recepção, à época, no Brasil, ver Buarque de Holanda (1985, pp. 289-305).

29 Embora em outra perspectiva (na busca da identidade da "sociedade brasileira"), Buarque de Holanda (1988, p. 125) estava atento a essa questão, observando que, com a implantação da República, o Estado "desenraizou-se" ainda mais do país. Segundo Faoro (1976, p, 64), fortificou-se o "arbítrio". Cf. também Carvalho (1996, espec. p. 379).

30 A esse respeito, ver Neves (1992, pp. 170-171). É claro que os problemas eleitorais não se reduziam à prática constitucional, pois a falta de garantia do voto secreto alimentava a fraude nas eleiçōes, assim como a inexistência de direito de voto para os analfabetos e mendigos (art. 70, $₫ 1^{\circ}$, incisos 1 e 2 , da Constituição) excluía do processo eleitoral ampla parcela da população: segundo os dados oficiais (IBGE, 1989, p. 72), 65,1\% da população a partir de 15 anos eram analfabetos em 
1900 e ainda 64,9\%, em 1920. Além do mais, o voto feminino permaneceu proibido até a reforma eleitoral de 1932 (Decreto 20.076, de 24/02/1932), após a queda da Primeira República e a revogação da Constituição de 1891 . De 1898 a 1926, a participação eleitoral oscilou entre 3,4\% e 2,3\% da população, segundo Faoro ([1958] 1985, pp. 620-621).

31 Sobre esse conceito, ver Loewenstein (1975, pp. 62-66).

32 A respeito da chamada "política dos governadores", ver, por exemplo, Faoro ([1958] 1985, pp. 563ss.); Carone (1969, pp. 103ss.; 1971, pp. 177ss.). Cardoso (1985, pp. 47ss.) designa-a "pacto oligárquico".

33 Nesse sentido, ver principalmente Vianna (1939, pp. 77ss.); Torres ([1914] 1978).

34 Cf., por exemplo, Vianna (1939, pp. 81, 91 e 111).

35 Evidentemente, trata-se, nesse contexto, de um emprego enviesado ou deslocado de "classe média", se consideramos, por exemplo, o significado que Thomas Piketty (2013, pp. 389-393) atribui a essa expressão: “'Classes populares' (os 50\% de baixo), 'classes médias' (os 40\% do 'meio', que dizer, os $40 \%$ incluídos entre os $50 \%$ de baixo e os $10 \%$ do topo) e classes superiores' (os 10\% do topo)” (p. 393). Nesse sentido, Rui Barbosa pertenceria a uma ínfima classe alta ou superior. Mas o próprio Piketty reconhece a relatividade de suas denominações, admitindo mesmo serem "arbitrárias e discutíveis", assim como aponta para outros empregos da expressão "classe média", inclusive para fins estratégicos de assegurar benefícios estatais (pp. 393-394). No nosso contexto, a expressão usada entre aspas refere-se apenas a uma camada urbana de profissionais que não se incluíam na massa dos socialmente subalternos nem na elite dos latifundiários ou grandes comerciantes, especialmente os vinculados à exportação de mercadorias. Reconheço, porém, que o Brasil da virada do século XIX para o século XX corresponde antes àqueles contextos político-históricos em relação aos quais, para Piketty, é pertinente opor "uma imensa maioria de 'classes populares e médias' (o povo) e uma ínfima minoria de 'classes superiores' (as 'elites')" (p. 394), tendo pertencido Rui Barbosa repita-se - a essas últimas.

36 "Mas a coqueluche da época era o presidencialismo norte-americano, que fizera rapidamente o progresso da grande nação amiga, como o parlamentarismo havia feito o da Inglaterra" (Roure, 1918-1920, vol. I, p. 354).

37 A respeito das relaçôes de subinclusão (ou subintegração) e sobreinclusão (ou sobreintegração), ver Neves (1994; 1992, 94ss. e 155ff.; 2006, pp. 261ss.).
38 Pontes de Miranda ([1928] 1981, pp. 82-83, com observaçôes racialistas). Voltarei a essa questão na seção "Ao Código Civil de 1916".

39 Cf. especialmente Vianna (1939, pp. 9-13).

$40 \mathrm{O}$ texto completo encontra-se em Coelho Rodrigues (1980).

41 O seu parecer foi adotado pela Comissão Especial em 18 de janeiro de 1902 (cf. Comissão Especial da Câmara dos Deputados, 1902).

42 Ver Bevilaqua (1906, 449-478), em resposta às críticas de Rui Barbosa, expressas no parecer (Barbosa, 1902) e na famosa Réplica de 31 de dezembro de 1902 (Barbosa, 1904), que levaram, respectivamente, às observações críticas e à chamada "tréplica" de Ribeiro (1902; 1905). Sobre essa polêmica e suas implicaçôes jurídico-políticas, ver o estudo pioneiro de Veronese (2012).

43 Para uma síntese sobre a elaboração do projeto, sua revisão pelo governo e sua tramitação no Congresso Nacional, ver Pontes de Miranda ([1928] 1981, pp. 83-86). A respeito do envolvimento de Rui Barbosa, inclusive do seu parecer jurídico apresentado na Comissão Especial do Senado em 1905 (Barbosa, 1968), ver Dantas (1962b).

44 "A data mental do Código (como do B. G. B. e do suíço) é bem 1899; não seria errôneo dizê-lo o antepenúltimo Código do século passado [XIX]" (Pontes de Miranda, [1928] 1981, p. 85).

45 As alterações para a inclusão legal do trabalhador rural só começaram a ocorrer a partir da entrada em vigor do Estatuto do Trabalhador Rural (Lei no 4.214, de 2 de março de 1963), mas de forma muito lenta e sem os correspondentes efeitos práticos (cf. Moraes Filho, 1982, pp. 111-115).

46 As restrições atuais aos direitos dos trabalhadores domésticos encontram apoio no parágrafo único do art. $7^{\circ}$ da Constituição brasileira. A nova Emenda à Constituição $n^{\circ} 72 / 2013$, que alterou esse dispositivo, aproximou os direitos dos empregados domésticos aos dos demais trabalhadores, principalmente para estender àqueles o FGTS. Entretanto, a taxa de informalidade ilegal permanece altíssima na contratação de empregados domésticos (73,7\% em 2009 - cf. M. Gomes, 2011).

47 Sobre as alterações decorrentes desta Lei, ver a sucinta exposição jurídica de Bueno (1972).

48 A esse respeito, manifestou-se Pontes de Miranda ([1928] 1981, p. 454): "Foi Clóvis Bevilaqua o mais favorável à mulher (arts. 251 e parágrafo único, 254, 287, 393 e 414, I), à filiação ilegítima (art. 367) e à solidariedade familiar (arts. 332, 409, 416, 447 e 467)". 
49 No tocante ao racialismo, afirmava este autor: "A benevolência jurídica, o exagerado afetivismo, que Clóvis Bevilaqua depois reconheceu como característica, e cercou de elogios, constituiu defeito de energia, resulta do elemento negro mesclado à população [...]. $\mathrm{O}$ negro e o indígena entravam como influências biológicas, e não sociológicas, isto é, de fatos sociais a fatos sociais. Não há institutos de direito negro ou indígena no direito brasileiro; mas há fatores negro e indígena no modo de ser e na atividade jurídica do brasileiro: estas influências terão de passar, e é proveitoso que se acelere a extirpação dos inconvenientes, que deles derivam" (Pontes de Miranda, [1928] 1981, pp. 445-446). Ele defendia, então, a oportunidade de "medidas eugênicas" (p. 447). Também conforme o racialismo dominante na época, Bevilaqua ([1922] 1975 , p. 194) referia-se a negros e índios como "raças afetivas". Sobre essa matéria, ver Grinberg (2008, espec. pp. 34-37). A respeito do "racismo" de Bevilaqua, ver Machado Neto (1969, p. 125).

50 "E falo somente desse socialismo que se nos apresenta como uma solução empírica das duras contingências do presente, e não desse produto genuíno da anarquia mental que investe contra a organização da propriedade, da família e do governo, sem saber que forças hão de substituir a essas que pretende eliminar" (Bevilaqua, 1906, p. 41). Essa segunda feição do socialismo era definida como "fermento produzido por um estado de inquietação, de constrangimento, de revolta em que se atormenta uma parte considerável do gênero humano" (p. 42). Cf. Gomes (1958, p. 43).

51 Cf. supra nota 49.

52 Loewenstein (1942, p. 122) caracterizou-a como "tuttifrutti internacional" e "coquetel constitucional".

53 De acordo com o art. 180 da Constituição de 1937, no entanto, restou ao presidente da República "expedir decretos-leis sobre todas as matérias de competência legislativa da União".

54 Cf. supra nota 1.

55 Como sugerem Lopes e Garcia Neto (2009, p. 2), em relação ao pensamento "crítico" no Brasil das décadas de 1920 e 1930. Na versão definitiva, publicada em espanhol, estes autores retiram esta expressão do trecho citado (idem, 2011, p. 106), mas o argumento permanece no artigo.

56 Parece-me equivocada a concepção segundo a qual a "multiplicidade da modernidade", no sentido de Eisenstadt, não comporta assimetrias. Na própria obra de Eisenstadt (2000), ao se falar do "surgimento" da modernidade na Europa Ocidental e da "transforma- ção da modernidade euro-ocidental na América (o exemplo dos Estados Unidos)", da "transformação da modernidade ocidental na Ásia (o exemplo do Japão)" e do "fundamentalismo como movimento moderno contra a modernidade" (estes são os títulos dos capítulos do livro de Eisenstadt), aponta-se para uma assimetria entre núcleos irradiadores de estruturas e ideias (semântica) e espaços sociais que as reproduzem e as transformam ou se confrontam com elas.

57 "Não se trata apenas de relativizar a oposição de local e universal, mas também de ver as reciprocidades perversas entre ex-colônia e nações imperialistas, subdesenvolvidos e desenvolvidos, periféricos e centrais etc., oposições politicamente mais relevantes e carregadas" (Schwarz, 2012, p. 170). A esse respeito, parece que as críticas de Franco (1976) e Bosi (2010, espec. p. 400) à posição de Schwarz tendem à simplificação. Ver supra nota 25. Cf. também Schwarz (2012, pp. 171-172).

58 Cf. supra nota 5.

\section{BIBLIOGRAFIA}

ALVES, José Carlos Moreira. (2003), A parte geral do projeto de Código Civil Brasileiro: subsídios históricos para o novo Código Civil Brasileiro. 2. ed. São Paulo, Saraiva.

BARBOSA, Rui. (1902), "Parecer do senador Ruy Barbosa sobre a redação do projecto da Câmara dos Deputados". Diário do Congresso Nacional, suplemento ao n. 126 de 27 de julho de 1902. Rio de Janeiro, Imprensa Nacional. - (1904), Réplica do senador Ruy Barbosa às defesas da redação do projecto da Câmara dos Deputados. Rio de Janeiro, Imprensa Nacional. - (1932-1934), Comentários à Constituição Federal Brasileira. Org. Homero Pires. São Paulo, Livraria Academica/Saraiva, 1932 (vol. I), 1933 (vols. II e III), 1934 (vol. V). . (1968), Código Civil: Parecer. Obras completas de Rui Barbosa. Rio de Janeiro, Ministério da Educação e Cultura, vol. XXXII (1905), tomo III.

BARRETO, Tobias. (2000), "A questão do poder moderador: o governo parlamentar no Brasil" [1871], in , Estudos de direito, Campinas, Bookseller, pp. 375-424. 
BEVILAQUA, Clóvis. (1906), Em defeza do projecto de código civil brazileiro. Rio de Janeiro/São Paulo/Belo Horizonte, Livraria Francisco Alves. (1975). "Características do direito pátrio" [1922], in Obra filosófica. Vol. II: Filosofia social e jurídica, São Paulo, Editora da Universidade de São Paulo/Grijalbo, pp. 185-212.

BOSI, Alfredo. (1992), "A escravidão entre dois liberalismos", in: , Dialética da colonização, São Paulo, Companhia das Letras, pp. 194-245.

(2010), "Um nó ideológico: sobre o enlace de perspectivas em Machado de Assis", in Ideologia e contraideologia: temas e variaçôes, São Paulo, Companhia das Letras, pp. 398-421.

BRANDÃO, Wilson. (1980), "Antônio Coelho Rodrigues: ensaio de bibliografia e crítica", in Antônio Coelho Rodrigues, Projeto do Código Civil Brasileiro, 2. ed., Brasília, Ministério da Justiça, pp. 1-33.

BRUNKHORST, Hauke. (1999), "Heterarchie und Demokratie", in Hauke Brunkhorst e Peter Niesen (orgs.), Das Recht der Republik, Frankfurt, Suhrkamp, pp. 373-385.

BUARQUE DE HOLANDA, Sérgio. (1985), Do Império à República. Vol. II. 5 da História Geral da Civilização Brasileira. Org. Sérgio Buarque de Holanda. 4. ed. São Paulo, Difel. . ([1936] 1988). Raízes do Brasil. 20 ed. Rio de Janeiro, José Olympio.

BUENO, José Antonio Pimenta. (1857), Direito publico brazileiro e analyse da constituição do Império. Rio de Janeiro, Villeneuve.

BUENO, Ruth. (1972), Regime jurídico da mulher casada. 3. ed. Rio de Janeiro, Forense.

CARDOSO, Fernando Henrique. (1985), "Dos governos militares a Prudente-Campos Sales", in Boris Fausto (org.), História geral da civilização brasileira, 4. ed., São Paulo, Difel, tomo III, vol. 1, pp. 13-50.

CARONE, Edgard. (1969), A Primeira República (1889-1930): texto e contexto. São Paulo, Difel.

CARVALHO, José Murilo de. (1996), A construção da ordem/Teatro de sombras. 2. ed. Parte II: Teatro de sombras: a política imperial. Rio de Janeiro, Editora UFRJ/Relume Dumará.
COELHO RODRIGUES, Antônio. (1980), Projeto do Código Civil Brasileiro. 2. ed. Brasília, Ministério da Justiça.

COMISSÃO ESPECIAL da Câmara dos Deputados. (1902), "Parecer da Comissão Especial". Projecto de Codigo Civil Brazileiro - Trabalhos da Comissão Especial da Câmara dos Deputados, vol. VIII. Rio de Janeiro, Imprensa Nacional, pp. 3-41.

CONSTANT, Benjamin. (1872), "Réflexions sur les constitutions et les garanties, avec une Esquisse de Constitution (1814-1818)", in Benjamin Constant, Cours de politique constitutionnelle ou collection des ouvrages publiés sur le gouvernement representative, 2. ed., Paris, Librairie de Gillaumin, vol. II, pp. 167-217. (1957), "Principes de politique" [1815], in _ a cevres. Org. Alfred Roulin. Paris, Gallimard, pp. 1063-1215.

DAMATTA, Roberto. (1991), A casa \& a rua. 4. ed. Guanabara, Koogan.

DANTAS, San Tiago. (1962), Figuras do direito. Rio de Janeiro, José Olympio.

. (1962A). "Rui Barbosa e a renovação da sociedade", in Figuras do direito, Rio de Janeiro, José Olympio, pp. 21-39. (1962b), "Rui Barbosa e o Código Civil", in , Figuras do direito, Rio de Janeiro, José Olympio, pp. 41-78. . (1962c), "Ciência e consciência: um estudo sobre Clóvis Bevilacqua", in Figuras do direito, Rio de Janeiro, José Olympio, pp. 79-93.

EISENSTADT, S. N. (2000), Die Vielfalt der Moderne. Trad. B. Schluchter. Frankfurt, Velbrück. FAORO, Raymundo. (1976), Machado de Assis: a pirâmide e o trapézio. 2. ed. São Paulo, Editora Nacional/Secretaria de Cultura, Ciência e Tecnologia do Estado de São Paulo.

- ([1958] 1985). Os donos do poder: formação do patronato político brasileiro. 6. ed. Porto Alegre, Globo, vol. 1.

FONSECA, Ricardo Marcelo. (2011), "A modernização frustrada: a questão da codificação civil no Brasil do século XIX”, in Ana Carolina Brochado Teixeira e Gustavo Pereira Leite Ribeiro (orgs.), Manual de teoria geral de direito civil. Belo Horizonte, Del Rey, pp. 13-34. 
(2012), "A noção de imaginário jurídico e a história do direito", in (org.), Nova história brasileira do direito: ferramentas e artesanias, Curitiba, Juruá, pp. 19-29.

FRANCO, Maria Sylvia de Carvalho. (1976), "As ideias estão no lugar”. Cadernos de Debate, 1. São Paulo, Brasiliense, pp. 61-64.

FREITAS, Augusto Teixeira de. (1878), Aditamento ao Codigo do Commercio. Rio de Janeiro, Perseverança, vol. 1. . ([1864] 1983), Código Civil - Esboço. Brasília, Ministério da Justiça/Fundação Universidade de Brasília, 2 vols. (1. ed. Rio de Janeiro).

([1857] 2003), Consolidação das Leis Civis. Brasília, Senado Federal, 2 vols. (ed. fac-similar da 3. ed. Rio de Janeiro, Garnier, 1876]. GOMES, Marcelo. (2011), “Trabalho doméstico: economia aquecida gera escassez de trabalho doméstico". Desafios do Desenvolvimento, ano 8 (66): 62-67. Brasília, Ipea.

GOMES, Orlando. (1958), Raizes históricas e sociológicas do Código Civil brasileiro. Salvador, Universidade da Bahia.

GRINBERG, Keyla. (2002), O fiador dos brasileiros: cidadania, escravidão e direito civil no tempo de Antonio Pereira Rebouças. Rio de Janeiro, Civilização Brasileira.

. (2008), Código Civil e cidadania. 3. ed. Rio de Janeiro, Zahar.

IBGE - Fundação do Instituto Brasileiro de Geografia e Estatística. (1989), Anuário Estatístico do Brasil-1989. Rio de Janeiro, IBGE.

KOLLE, Same. (1991), "Le Code Noir et les lumières françaises: le paradoxe d'un silence psychohistorique", in Ambroise Kom e Lucienne Ngoué (orgs.), Le Code Noir et l'Afrique, Ivry, Nouvelles du Sud, pp. 235-242.

LEVAGGI, Aberlardo. (1988), "Influencia de Teixeira de Freitas sobre el projecto de Código Civil Argentino en materia de relaciones de familia: las fuentes utilizadas por Vélez Sarsfield”, in Sandro Shipani (org.), Augusto Teixeira de Freitas e il diritto latinoamericano, Pádua, Cedam , pp. 399-426.

LOEWENSTEIN, Karl. (1942), Brazil under Vargas. Nova York, Macmillan.
(1975), Verfassungslehre. Trad. Rüdiger Boerner. 3. ed. Tübingen, Mohr.

LOPES, José Reinaldo de Lima \& GARCIA NETO, Paulo Macedo. (2009), "Critical legal thought”. Artigos Direito GV-Working Papers, 37. São Paulo, Escola de Direito de São Paulo da Fundação Getulio Vargas. [versão definitiva em espanhol (2011), "Pensamiento jurídico crítico en Brasil (1920-1940)", in Mauricio García Villegas e María Paula Saffon (coords.), Crítica jurídica comparada, Bogotá, Universidad Nacional de Colombia, pp. 105-142].

LUHMANN, Niklas. (1975), "Die Weltgesellschaft", in , Soziologische Aufklärung 2: Aufsätze zur Theorie der Gesellschaft, Opladen, Westdeutscher, pp. 51-71.

(1980), "Gesellschaftliche Struktur und semantische Tradition", in______ Gesellschaftsstruktur und Semantik: Studien zur Wissenssoziologie der modernen Gesellschaft, Frankfurt, Suhrkamp, vol. 1, pp. 9-71.

(1986), Ökologische Kommunikation: Kann die moderne Gesellschaft sich auf ökologische Gefährdungen einstellen?. Opladen, Westdeutscher.

. (1993), Das Recht der Gesellschaft. Frankfurt, Suhrkamp.

. (1995a), Die Kunst der Gesellschaft. Frankfurt, Suhrkamp.

(1995b), "Kultur als historischer Begriff", in__, Gesellschaftsstruktur und Semantik: Studien zur Wissenssoziologie der modernen Gesellschaft, Frankfurt, Suhrkamp, 4, pp. 31-54.

. (1997), Die Gesellschaft der Gesellschaft.

Frankfurt, Suhrkamp, 2 tomos.

(1998), "Der Staat des politischen Systems: Geschichte und Stellung in der Weltgesellschaft", in Ulrich Beck (org.), Perspektiven der Weltgesellschaft, Frankfurt, Suhrkamp, pp. 345-380.

. (2000). Die Politik der Gesellschaft. Frankfurt, Suhrkamp.

MACHADO DE ASSIS, Joaquim Maria. (1955), "Crônica de 29 de dezembro de 1861 no $D i$ ário do Rio de Janeiro" [1861], in Obras Completas de Machado de Assis, tomo 22: Crônicas, vol. 1 (1859-1863). Rio de Janeiro/São Paulo/ Porto Alegre, W. M. Jackson Inc. Editores, pp. 102-109. 
MACHADO NETO, A. L. (1969), História da idéias jurídicas no Brasil. São Paulo, Grijalbo/ Editora da Universidade de São Paulo.

MÁRTINEZ PAZ, Enrique. (1927), Freitas y su influencia sobre el Código Civil Argentino. Córdoba, Imprensa de la Universidad.

MAXIMILIANO, Carlos. (1948), Comentários à Constituição brasileira. 4. ed. Rio de Janeiro/ São Paulo, Freitas Bastos, vol. 1.

MEDINA, Diego Eduardo López. (2008), Teoría impura del derecho: la transformación de la cultura jurídica latinoamericana. Bogotá, Legis.

MEIRA, Sílvio. (1983), Teixeira de Freitas: o jurisconsulto do Império. 2. ed. Brasília, Cegraf.

MERCADANTE, Paulo. (1980), "A dualidade do direito privado", in , A consciência conservadora no Brasil: contribuição ao estudo da formação brasileira. 3. ed. Rio de Janeiro, Nova Fronteira, pp. 177-194.

MIGNOT, Dominique-Aimé. (2007), "La matrice romaine de l'Édit de Mars 1865, dit le Code Noir", in Jean-François Niort (org.), Du Code Noir au Code Civil: jalons pour l'histoire du droit en Guadeloupe. Perspectives comparées avec Martinique, la Guyane et la République d'Haïti, Paris, L'Harmattan, pp. 87-98.

MONTORO, André Franco. (1973), "Filosofia do direito e colonialismo cultural: transplante de institutos jurídicos inadequados à realidade brasileira”. Revista de Informação Legislativa, X (37): 3-20. Brasília, Senado Federal.

MORAES FILHO, Evaristo. (1982), "Proteção do trabalhador agrícola", in Direito do trabalho: páginas de história e outros ensaios, São Paulo, LTr, pp. 99-115.

NABUCO, Joaquim. ([1897-1899] 1997), Um estadista do Império. 5. ed. Rio de Janeiro, Topbooks, 2 vols. (1. ed. 3 vols.).

NEVES, Marcelo. (1992), Verfassung und Positivität des Rechts in der peripheren Moderne: Eine theoretische Betrachtung und eine Interpretation des Falls Brasilien. Berlim, Duncker \& Humblot. . (1994), "Entre subintegração e sobreintegração: a cidadania inexistente". Dados - Revista de Ciências Sociais, 37 (2): 253-276.

. (2006), "Einige Probleme mit Niklas Luhmanns Auffassung von den Staaten der
Weltgesellchaft". Soziale Systeme: Zeitschrift für Soziologische Theorie, 12 (2): 247-273. . (2008), Entre Têmis e Leviatã: uma relação difícil - o Estado democrático de direito a partir e além de Luhmann e Habermas, 2. ed., São Paulo, Martins Fontes.

. (2009), Transconstitucionalismo. São Paulo, WMF Martins Fontes.

. (2012). "Komplexitätssteigerung unter mangelhafter funktionaler Differenzierung: Das Paradox der sozialen Entwicklung Lateinamerikas", in Peter Birle, Matias Dewey e Aldo Mascareño (orgs.), Durch Luhmanns Brille: Herausforderung an Politik und Recht in Lateinamerika und in der Weltgesellschaft, Berlim, Springer VS, pp. 17-27.

PACHECO, Cláudio. (1958), Tratado das constituiçôes brasileiras. Rio de Janeiro/São Paulo, Freitas Bastos, vol. 1.

PIKETTY, Thomas. (2013), Le capital au XXIe siècle. Paris, Seuil.

PONTES DE MIRANDA, Francisco Cavalcanti. ([1928] 1981), Fontes e evolução do direito civil brasileiro. 2. ed. Rio de Janeiro, Forense.

RIBEIRO, Ernesto Carneiro. (1902), Ligeiras observaçôes sobre as emendas do dr. Ruy Barbosa feitas à redação do Projecto de Código Civil. Bahia, Dois Mundos

- (1905), A redacção do Projecto do Código Civil e a réplica do dr. Ruy Barbosa. Bahia, Dois Mundos. RIBEIRO, Pedro Henrique. (2013), "Luhmann 'fora do Lugar'?: como a 'condição periférica' da América Latina impulsionou deslocamentos na teoria dos sistemas". Revista Brasileira de Ciências Sociais, 28 (83): 105-123.

RICHARD, Jérémy. (2010), “Du Code Noir de 1685 au Projet de 1829: de la semi-réification à l'humanisation de l'esclave Noir', in Tanguy le Marc'Hadour e Manuel Carius, Esclavage et droit: du Code noir à nos jours, Arras, Artois Presses Université, pp. 53-90.

RODRIGUES, José Carlos. (1863), Constituição Política do Império do Brazil [...]. Rio de Janeiro, Laemmert.

ROMERO, Ś́lvio. (1894), Doutrina contra doutrina: o evolucionismo e o positivismo na República do Brasil. Rio de Janeiro, J. B. Nunes, $1^{\text {a }}$ série. 
([1888] 1960), História da literatura brasileira. 6. ed. Rio de Janeiro, José Olympio, tomo 1.

ROURE, Agenor. (1918-1920), A Constituinte republicana. Rio de Janeiro, Imprensa Nacional, 1918 (vol. II) - 1920 (vol. I).

SALA-MOLINS, Louis. (1987), Le Code Noir ou le calvaire de Canaan. Paris, Presses Universitaires de France.

SANTIAGO, Silviano. (2002), "Introdução", in (org.), Intérpretes do Brasil, Rio de Janeiro, Nova Aguilar, vol. 1, pp. xiii-xlviii.

SCHWARZ, Roberto. ([1977] 2000), “As idéias fora do lugar", in , Ao vencedor as batatas: forma literária e processo social nos inícios do romance brasileiro, 4. ed., São Paulo, Duas Cidades/Editora 34, pp. 9-31 [1 1 a ed. 1977]. . (2012), "Por que 'ideias fora do lugar'?, in , Martinha versus Lucrécia: ensaios e entrevistas, São Paulo, Companhia das Letras, pp. 165-172.

SOUSA, Joaquim Rodrigues de. (1867), Analyse e commentário da constituição política do Império do Brazil ou theoria e pratica do governo constitucional brazileiro. São Luiz, B. de Mattos, vol. I.

SOUZA, Jessé. (2000), "Multiculturalism and democracy in Gilberto Freyre's thinking", in Marcelo Neves e Julian Hottinger (orgs.), Federalism, rule of law and multiculturalism in Brazil, Fribourg, Institute of Federalism/Basel/ Helbing \& Lichtenhahn, pp. 103-149. . (2003), A construção social da subcidadania: para uma sociologia politica da modernidade periférica. Belo Horizonte/ Editora Rio de Janeiro, Editora UFMG/Iuperj. . (2013), "Niklas Luhmann, Marcelo Neves e o 'culturalismo cibernético' da moderna teoria sistêmica", in Roberto Dutra e João Paulo Bachur (orgs.), Dossiê Niklas Luhmann, Belo Horizonte, UFMG, pp. 149-182.

STICHWEH, Rudolf. (2000), Die Weltgesellschaft: Soziologische Analysen. Frankfurt, Suhrkamp.

SURGIK, Aloísio. (1988), "O pensamento codificador de Augusto Teixeira de Freitas em face da escravidão no Brasil”, in Sandro Shipani (org.), Augusto Teixeira de Freitas e il diritto latinoamericano, Pádua, Cedam, pp. 427-247.
TORRES, Alberto. ([1914] 1978), A organização nacional. Primeira parte: A Constituição. 3. ed. São Paulo, Editora Nacional.

VERONESE, Alexandre. (2012), "Entre os dispositivos conceituais e a gramática: o direito e a política na formação do Código Civil de 1916”. Escritos, VI: 297-338. Rio de Janeiro, Fundação Casa de Rui Barbosa.

VIANNA, Oliveira. (1939), O idealismo da Constituição. 2. ed. São Paulo/Rio de Janeiro/Recife/ Porto Alegre, Editora Nacional.

VILLAS BÔAS FILHO, Orlando. (2009), Teoria dos sistemas e direito brasileiro. São Paulo, Saraiva.

WALLERSTEIN, Immanuel. (2006), World-systems analysis: an introduction. 4. ed. Durham/ Londres, Duke University Press. 



\section{IDEIAS EM OUTRO LUGAR? CONSTITUIÇÃO LIBERAL E CODIFICAÇÃOO DO DIREITO PRIVADO NA VIRADA DO SÉCULO XIX PARA O SÉCULO XX NO BRASIL}

\section{Marcelo Neves}

Palavras-chave: Estado brasileiro; Sociedade mundial; Constituição liberal; Codificação do direito privado; Teoria dos sistemas.

$\mathrm{O}$ artigo analisa, partindo de pressupostos da teoria dos sistemas em uma perspectiva crítica, a relação entre estrutura social e semântica no Estado brasileiro da passagem do século XIX para o século XX, considerando especificamente as questôes do constitucionalismo liberal e da codificação do direito privado. Em primeiro lugar, o autor procura afastar-se do modelo dos "intérpretes do Brasil", para caracterizar o Estado brasileiro como organização político-jurídica territorial no âmbito da sociedade moderna como sociedade mundial. No segundo momento, o autor discute as dificuldades da adoção de um código civil durante o Império. A esse respeito, aponta para a dificuldade das ideias jurídicas liberais no âmbito de estruturas socioeconômicas locais não liberais. $\mathrm{Na}$ terceira parte, o autor trata das condições de surgimento da Constituição de 1891, enfatizando o deslocamento do sentido e função das ideias jurídico-políticas liberais no contexto do Estado brasileiro da Primeira República. Em seguida, aborda as condiçôes do surgimento e o significado prático do Código Civil de 1916, considerando novamente o deslocamento das ideias jurídicas liberais no contexto do Estado brasileiro. Por fim, o autor conclui com a formulação paradoxal de que as ideias liberais, naquele contexto, atuaram ao mesmo tempo como ideias em outro lugar (a sociedade no âmbito do Estado brasileiro) e no mesmo lugar (a sociedade mundial).

\section{IDEAS IN ANOTHER PLACE? LIBERAL CONSTITUTION AND THE CODIFICATION OF PRIVATE LAW}

\section{Marcelo Neves}

Keywords: Brazilian State; World society; Liberal constitution; Private law codification; Systems theory.

Based on assumptions of systems theory in a critical perspective, this paper analyzes the relationship between social structure and semantics in the Brazilian State at the turn of nineteenth century, specifically considering the issues of liberal constitutionalism and codification of private law. First, the author seeks to depart from the model of "interpreters of Brazil" in order to characterize the Brazilian State as a territorial politicallegal organization within the modern society as world society. In the second section, the author discusses the difficulties in adopting a civil code during the Brazilian Empire. In this regard, he points to the difficulty of liberal legal ideas under non-liberal local socioeconomic structures. In the third part of the article, the author deals with the conditions of emergence of the 1891 Constitution, emphasizing the shift of meaning and function of the liberal legal-political ideas in the context of the Brazilian State of the "First Republic". He then addresses the conditions of emergence and the practical meaning of the Civil Code of 1916 , considering again the displacement of liberal legal ideas in the context of the Brazilian state. Finally, the author takes distance from the notion of "misplaced ideas" to complete with the paradoxical formulation that liberal ideas, in that context, acted as both ideas in another place (society in the scope of the Brazilian State) and in the same place (the world society).

\section{DES IDÉES AILLEURS? CONSTITUTION LIBÉRALE ET CODIFICATION DU DROIT PRIVÉ AU TOURNANT DU XIXe VERS LE XXe SIËCLE AU BRÉSIL}

\section{Marcelo Neves}

Mots-clés: État brésilien; Société mondiale; Constitution libérale; Codification du droit privé; Théorie des systèmes.

L'article analyse, à partir d'une perspective critique des hypothèses de la théorie des systèmes, la relation entre la structure sociale et sémantique dans l'État brésilien au tournant du XIXe. Il considère spécifiquement les questions du constitutionnalisme libéral et de la codification du droit privé. L'auteur cherche, tout d'abord, à s'écarter du modèle des "interprètes du Brésil" pour caractériser l'État brésilien comme une organisation politique et juridique territoriale dans le cadre de la société moderne en tant que société mondiale. L'auteur aborde, ensuite, les difficultés de l'adoption d'un code civil sous l'Empire et met en avant la difficulté des idées juridiques libérales dans le cadre des structures socioéconomiques locales non libérales. Dans une troisième partie, l'auteur analyse les conditions de l'élaboration de la Constitution de 1891, mettant l'accent sur le déplacement des idées juridiques libérales dans le contexte de l'État brésilien de la Première République. Il aborde ensuite les conditions de l'émergence et le rôle pratique du Code Civil de 1916, tout en considérant le déplacement des idées libérales dans le cadre de l'État brésilien. Finalement, l'auteur conclut avec la formulation paradoxale selon laquelle les idées libérales, dans ce contexte, ont également, en tant qu'idées, agi ailleurs (la société dans le cadre de l'État brésilien) et au même endroit (la société mondiale). 